\title{
Salt Reduction Initiatives in the Eastern Mediterranean Region and Evaluation of Progress towards the 2025 Global Target: A Systematic Review
}

\author{
Ayoub Al-Jawaldeh ${ }^{1} \mathbb{D}$, Mandy Taktouk ${ }^{2}$, Aya Chatila ${ }^{2}$, Sally Naalbandian ${ }^{3}{ }^{\mathbb{D}}$, \\ Al-Anoud Mohammed Al-Thani ${ }^{4,+}$, Majid M. Alkhalaf ${ }^{5,+}$, Salima Almamary ${ }^{6,+}$, Rawhieh Barham ${ }^{7,+}{ }^{+}$, \\ Nimah M. Baqadir ${ }^{5,+}$, Faisal F. Binsunaid ${ }^{8,+}$, Gihan Fouad ${ }^{9,+}$ and Lara Nasreddine ${ }^{2, *}$ \\ Citation: Al-Jawaldeh, A.; Taktouk, \\ M.; Chatila, A.; Naalbandian, S.; \\ Al-Thani, A.-A.M.; Alkhalaf, M.M.; \\ Almamary, S.; Barham, R.; Baqadir, \\ 1 Regional Office for the Eastern Mediterranean (EMRO), World Health Organization (WHO), \\ Cairo 11435, Egypt; aljawaldeha@who.int \\ 2 Nutrition and Food Sciences Department, Faculty of Agriculture and Food Sciences, American University of \\ Beirut, Beirut 11-0236, Lebanon; mt86@aub.edu.lb (M.T.); aac25@mail.aub.edu (A.C.) \\ 3 Science and Agriculture Library, American University of Beirut, Beirut 11-0236, Lebanon; sn23@aub.edu.lb \\ 4 Health Promotion and NCD Division, Public Health Department, Ministry of Public Health, Doha 42, Qatar; \\ malthani@moph.gov.qa \\ 5 National Nutrition Committee, Saudi Food and Drug Authority, Riyadh 13312-6288, Saudi Arabia; \\ m_khalaf75@hotmail.com (M.M.A.); nimahbaqadir@gmail.com (N.M.B.) \\ 6 Nutrition Department, Ministry of Health, Muscat 393, Oman; dr.salima.almamary@gmail.com \\ 7 Nutrition Department, Ministry of Health, Amman 11118, Jordan; majeda_barham@hotmail.com \\ 8 Healthy Food Department, Saudi Food and Drug Authority, Riyadh 13312-6288, Saudi Arabia; \\ ffsunaid@sfda.gov.sa \\ 9 National Nutrition Institute, Cairo 11435, Egypt; gihan_fouad@yahoo.com \\ * Correspondence: ln10@aub.edu.lb; Tel.: +961-1-350000 (ext. 4547) \\ + Authors contributed equally (listed in alphabetical order).
} N.M.; Binsunaid, F.F.; et al. Salt Reduction Initiatives in the Eastern Mediterranean Region and Evaluation of Progress towards the 2025 Global Target: A Systematic Review. Nutrients 2021, 13, 2676. https://doi.org/10.3390/nu13082676

Academic Editor: Helen Croker

Received: 23 June 2021

Accepted: 28 July 2021

Published: 31 July 2021

Publisher's Note: MDPI stays neutral with regard to jurisdictional claims in published maps and institutional affiliations.

Copyright: (c) 2021 by the authors. Licensee MDPI, Basel, Switzerland. This article is an open access article distributed under the terms and conditions of the Creative Commons Attribution (CC BY) license (https:// creativecommons.org/licenses/by/ $4.0 /)$.

\begin{abstract}
This study aims at identifying national salt reduction initiatives in countries of the Eastern Mediterranean Region and describing their progress towards the global salt reduction target. A systematic review of published and grey literature was conducted. Key characteristics of strategies were extracted and classified according to a pre-defined framework: salt intake assessments; leadership and strategic approach; implementation strategies; monitoring and evaluation of program impact. Salt intake levels were estimated in 15 out of the 22 countries $(68 \%)$, while national salt reduction initiatives were identified in $13(59 \%)$. The majority of countries were found to implement multifaceted reduction interventions, characterized by a combination of two or more implementation strategies. The least common implementation strategy was taxation, while the most common was reformulation (100\%), followed by consumer education (77\%), initiatives in specific settings (54\%), and front of pack labelling (46\%). Monitoring activities were conducted by few countries (27\%), while impact evaluations were lacking. Despite the ongoing salt reduction efforts in several countries of the region, more action is needed to initiate reduction programs in countries that are lagging behind, and to ensure rigorous implementation and evaluations of ongoing programs. Such efforts are vital for the achievement of the targeted $30 \%$ reduction in salt intake.
\end{abstract}

Keywords: salt; reduction; strategy; implementation; evaluation; Eastern Mediterranean Region

\section{Introduction}

Cardiovascular diseases (CVD) are the leading cause of mortality worldwide, resulting in around 17.9 million deaths each year and representing 31\% of global deaths [1]. The principal risk factor for CVD is high blood pressure (HBP) [2], with excessive sodium intake being recognized as a significant contributor to both HBP and CVD mortality [3]. Based on the recent Global Burden of Disease (GBD) study, HBP was found to account for 
10.4 million deaths and 218 million disability-adjusted life years (DALYs) in 2017, while excess sodium intake contributed to 3.2 million deaths and 70 million DALYs [4].

The World Health Organization (WHO) has recommended the reduction of salt/sodium intakes as a 'best buy', acknowledging it as one of the most cost-effective and feasible approaches to reduce the risk of CVD, stroke, and coronary heart disease (CHD) [5]. While several observational analyses have disputed the nature and magnitude of the association between sodium and vascular outcomes [6-9], available evidence supports the lowering of the population's sodium consumption as an effective public health strategy $[10,11]$. A recent systematic review of prospective studies showed a direct association between urinary excretion of sodium and the risk of CVD mortality, this association being more significant at sodium intakes exceeding $2.4 \mathrm{~g} /$ day [11]. The United Kingdom's sodium reduction strategy also provided support with regards to the feasibility and impact of such interventions, showing a 15\% decrease in the population's sodium intake between 2003 and 2011 [12], paralleled by a reduction in the population's average blood pressure by $3 / 1.4 \mathrm{~mm} \mathrm{Hg}$ [13]. In 2013, at the 66th World Health Assembly, the WHO Member States adopted the global target of a $30 \%$ relative reduction in mean population intake of sodium by the year 2025, against a 2010 baseline (Target 4) [14]. This target is one of the nine voluntary global targets for the worldwide reduction of non-communicable diseases (NCDs), including CVDs [15]. Efforts to reach the global target on sodium reduction are also expected to contribute towards achieving the Sustainable Development Goals (SDGs), including Target 3.4 of reducing premature NCD-related mortality by at least a third [16].

The Eastern Mediterranean Region (EMR), which includes 22 countries and a population of approximately 580 million people, is a region that harbors a high burden of CVD [17]. A recent study based on the GBD 2015 data for the EMR showed that CVD contributed to the loss of nearly 33 million years of life due to premature mortality or disability, and to more than 1.3 million deaths, thus accounting for approximately one-third of all deaths in the region [18]. This study also showed that HBP was the most important risk factor for CVD in the EMR [18], and that high sodium intakes were amongst the leading dietary risk factors [18]. Over the last decade, countries of the EMR have been working towards attaining the global NCD targets, including the reduction of mean population sodium intake by 30\% [19]. In fact, the WHO Regional strategy on nutrition 2010-2019 [20] has included a number of specific objectives relating to the prevention of diet-related NCDs, with one of these objectives focusing specifically on the reduction of mean population intake of salt/sodium by 30\% [20]. This was followed by the adoption of the new Strategy on Nutrition for the Eastern Mediterranean Region 2020-2030 in October 2019, to further assist countries of the region in fostering their action on nutrition, including the reduction of salt/sodium intakes [21]. However, up till today, there has been no systematic and indepth appraisal that focuses specifically on national salt reduction initiatives in countries of the EMR. It is in this context that we conducted this systematic review with the aim of identifying and documenting existing national salt reduction strategies in countries of the EMR, providing an overview of initiatives that are implemented by countries of the region to reduce population salt intake, and describing progress towards the global NCD salt reduction target of 2025 .

\section{Materials and Methods}

The methods and search strategy adopted in the present study were based on the approach described by Trieu et al. and Santos et al. [10,22]. In brief, data pertinent to population salt reduction initiatives were obtained through a series of steps allowing for maximum coverage of the 22 countries of the EMR. This included a search of peerreviewed and grey literature published up to March 2021, as well as seeking Supplementary Information by directly contacting program country leaders (Figure 1). 


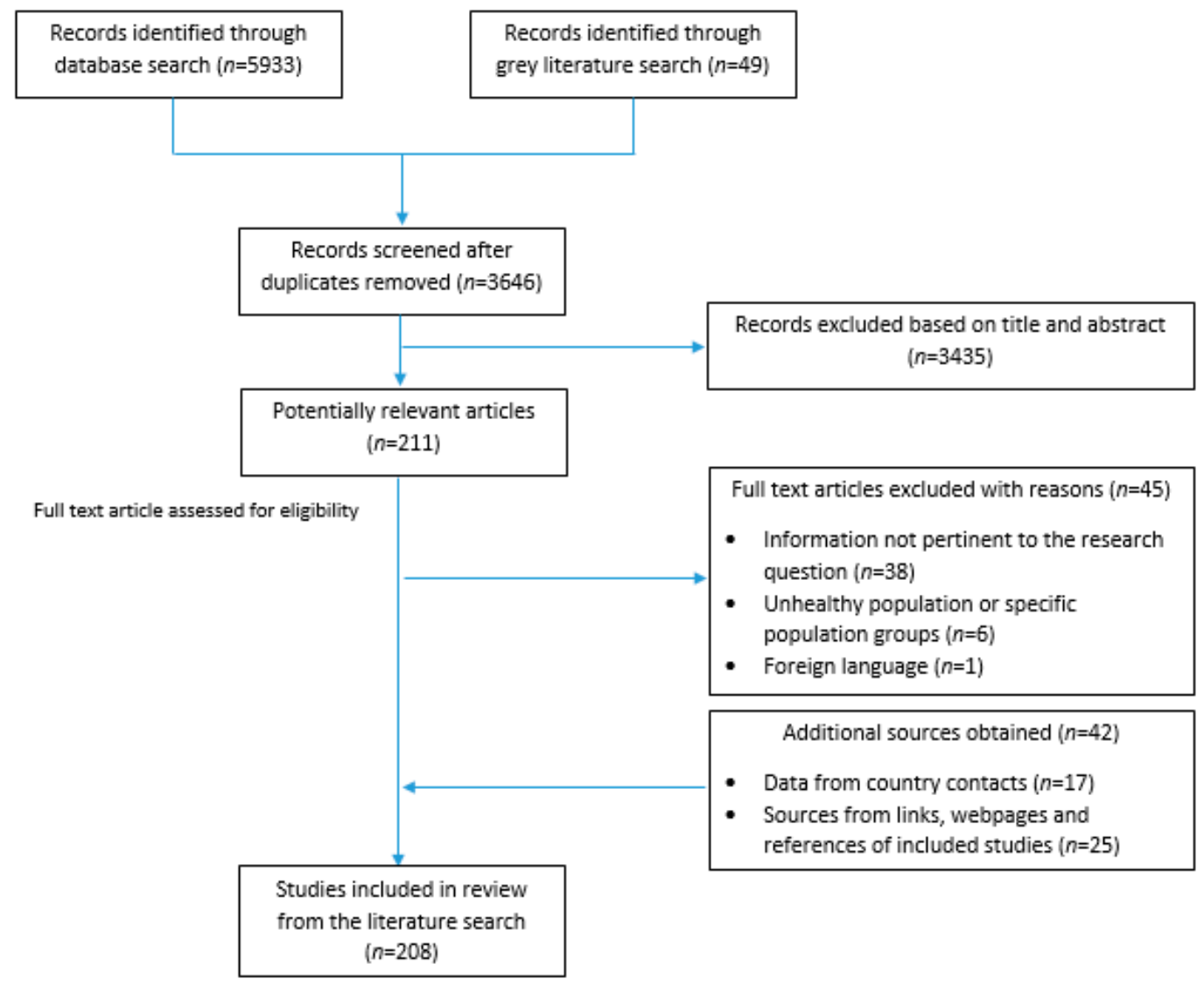

Figure 1. Search and identification process of potential references from the literature.

\subsection{Search Strategy}

Eleven electronic databases were searched between 26 and 31 January 2021, including four Arabic databases. Accordingly, the following databases were consulted for the search: CAB Direct, Directory of Open Access Journals, Google Scholar, MEDLINE OVID interface (1946 to present), PubMed, Scopus, Web of Science Core Collections, Al Manhal, Arab World Research Source (AWRS), E-Marefa and Iraqi Academic Scientific Journals (IASJ); the last four being specific to the Arab region. In addition to using controlled vocabulary (MeSH in PubMed and MEDLINE), a comprehensive list of search terms was used in the title/abstract/keyword fields to cover the four concepts (1) salt, (2) reduction OR intake, (3) policy, and (4) EMR countries. The detailed list of search terms is shown in Appendix A, and an example of a database search is shown in Table S1. The search was limited to materials published post 1995 in English, Arabic, and French languages only. Newly published articles after the execution of the initial search were identified through email alerts (up until 22 March 2021).

A search of the grey literature was also conducted, using OpenGrey, Google, World Action on Salt and Health, the Global Database on the Implementation of Nutrition Action (GINA), the WHO EMRO (Regional Office for the Eastern Mediterranean) website and governmental websites (e.g., Ministries of Health). The search was limited to the English, Arabic, and French languages only and published post 1995.

Articles identified through the search of online databases and grey literature were exported to EndNote X9 (Version 18.0.0.10063). Two independent researchers (MT and AC) screened the titles, abstracts and full text articles of the potentially relevant articles, based on the inclusion and exclusion criteria described in the section below. The few discrepancies from the two screening stages were discussed and resolved by the two researchers. 


\subsection{Inclusion and Exclusion Criteria}

Articles were included in the review if they provided information pertinent to salt intake assessment, or the development, implementation, monitoring, progress, or evaluation of national salt reduction initiatives at the national level. As per the approach adopted by Trieu et al. [10], the definition of a national salt reduction initiative was based on having the involvement of a governmental entity, and at least one of the following components: (1) a document that presents a national plan of action to decrease the population salt intake; (2) a program of work that involves the food industry for product reformulation, (3) consumers education programs or awareness campaigns aimed at improving knowledge, attitudes, and behavior (KAB) towards salt; (4) front of pack labelling (FOPL) schemes that specifically include salt, (5) taxation policies targeting high-salt foods, or unhealthy foods if the definition of the latter includes high salt or sodium; and (6) salt reduction initiatives in specific settings (schools, hospitals, workplaces).

Articles were excluded if they were based on randomized-control trials or case-control studies; focusing on unhealthy individuals or specific populations (pregnant women, individuals on therapeutic diets, etc.). Individual articles were included if they were published after 1995, or if they were in languages other than English, Arabic, and French.

\subsection{Data Extraction}

Data extraction was then conducted by one researcher (MT), and a second researcher (LN) reviewed the data for accuracy. Any inconsistency was resolved through discussion until reaching consensus. For each national salt reduction strategy, the key characteristics were entered into a database that was constructed by the researchers, and examined in relation to baseline assessments (population intake, levels in food products, KAB), leadership and strategic approach, implementation strategies (food reformulation, consumer education, FOPL, interventions in public institution settings, taxation), monitoring (population intake, levels in food products, KAB), and evaluation of program impact $[10,22,23]$.

\subsection{Seeking Supplementary Information}

A standardized questionnaire was developed based on the one adopted by Trieu et al. [10] and sent to country experts or program leaders in the region to verify and obtain supplementary country-specific data. Experts or program leaders were invited to collaborate on the study and fill the questionnaire and/or pass it on to their contacts to gather more information and provide the needed details. The additional data obtained from the questionnaires were utilized to update the database.

\subsection{Analysis}

Core characteristics for each national salt reduction strategy were entered into a database according to a pre-defined framework that includes baseline assessments; strategic approach; types of implementation strategies; monitoring data; and evaluation of program impact. Countries were then classified as 'having a developed strategy', 'having a planned strategy', or 'having no strategy'. Strategies were considered to be "planned" if the salt reduction initiatives were still being developed or if the strategic action plan had been already developed but without evidence of implementation [10]. A quantitative assessment of the proportion of countries reporting each characteristic was performed, based on percentages.

\section{Results}

\subsection{Search Results}

A total of 208 peer-reviewed articles, grey literature documents, and websites were obtained from the literature search; 166 were peer-reviewed articles and 42 were additional sources obtained from links, webpages, and references from within the included studies, or from country contacts via the completed questionnaires (Figure 1). 


\subsection{Salt Intake Assessment}

In the EMR, seven countries (32\%) including Afghanistan, Djibouti, Libya, Qatar, Somalia, Syria and Yemen do not have any estimate of salt intake in their population, (with the exception of estimates based on Bayesian modelling, which were not taken into consideration in this review) [24]. In contrast, 15 countries (68\%) were found to have one or more estimates of population salt intake (Table S2), with some studies reporting salt intake at the national level while others targeted specific regions within countries [25-88]. Twenty-four urine collection, which is considered as the gold standard for the assessment of salt intake, was conducted in 11 countries of the region (50\%) (Egypt, Iran, Iraq, Jordan, KSA, Lebanon, Morocco, Oman, Pakistan, Tunisia, and the UAE) (Table S2). Spot urinary excretion studies were also conducted in nine countries (41\%) (Egypt, Iran, Jordan, Lebanon, Morocco, Oman, Pakistan, Palestine, and Sudan) (Table S2). Dietary assessment of salt intake based on the use of food frequency questionnaires (FFQs), $24 \mathrm{~h}$ recalls or records has also been conducted in 12 countries (55\%), including Bahrain, Egypt, Iran, Jordan, KSA, Kuwait, Lebanon, Morocco, Oman, Pakistan, Tunisia, and the UAE. Household budget surveys have also been used in Jordan (Table S2).

The most recent national estimates of sodium/salt intake levels are presented in Figure 2 based on urinary excretion, and in Figure 3 based on dietary assessment. Based on urinary excretion, the highest level of salt intake was observed in Morocco (10.6 g/day), while the lowest was observed in Lebanon (5.6 g/day) and the UAE (6.8 g/day) (Figure 2). Based on dietary assessment, the highest levels of salt intake were observed amongst Iranian children and adolescents (14.3-16.2 g/day) and adults in Bahrain (9.3-13.3 g/day) and Lebanon (10.9 g/day). Per capita estimates were also high in Oman (11.5 g/day) and Tunisia (10.2 g/day) (Figure 3). Overall, Figures 2 and 3 show that salt intake levels were all above the WHO upper limit of $5 \mathrm{~g} /$ day in all countries, except for data reported amongst under-5 children.

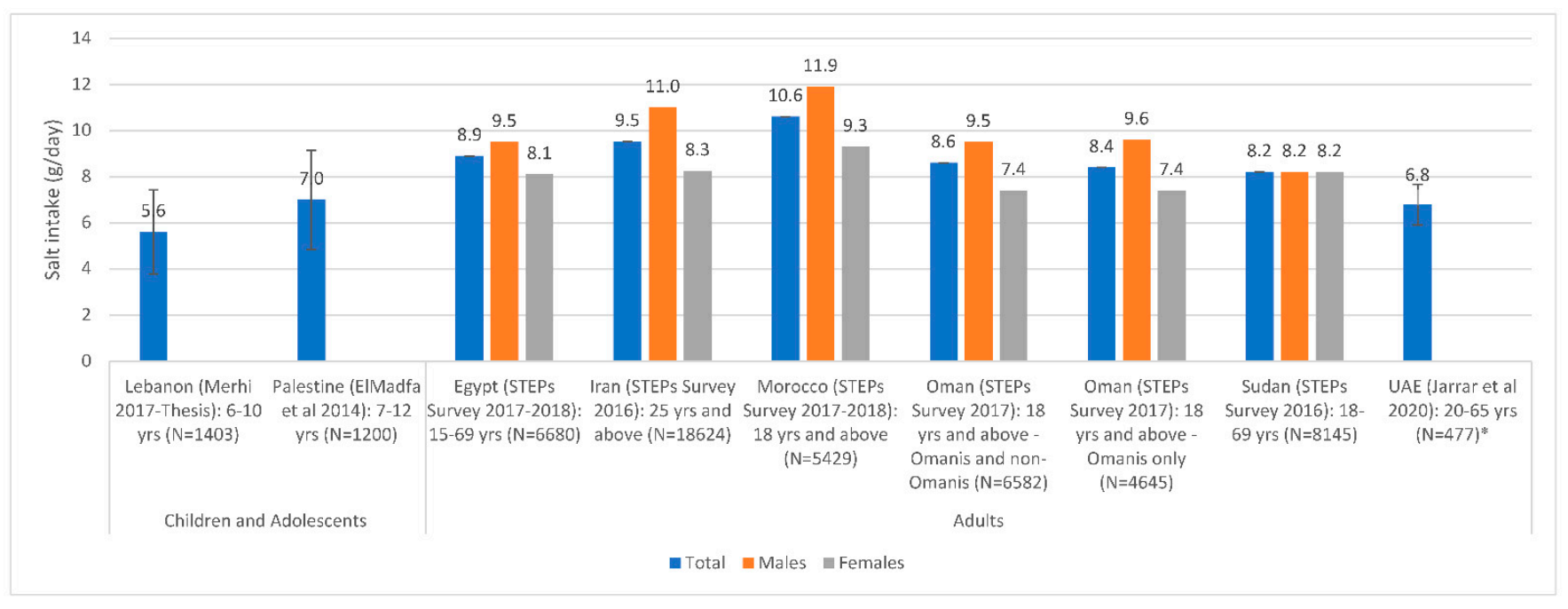

Figure 2. Salt intake estimates based on national urinary excretion studies in countries of the EMR\#. Abbreviations: EMR: Eastern Mediterranean Region; UAE: United Arab Emirates. References: For Children and Adolescents: Lebanon: Merhi 2017-Thesis [63]; Palestine: ElMadfa et al., 2014 [81]. For Adults: Egypt: STEPs Survey 2017-2018 [29]; Iran: STEPs Survey 2016 [33,36]; Morocco: STEPs Survey 2017-2018 [89]; Oman: STEPs Survey 2017 [76,90]; Sudan: STEPs Survey 2016 [82]; UAE: Jarrar et al., 2020 [87]. *: All studies were based on spot urine assessment with the exception of UAE (Jarrar et al., 2020), which was based on a $24 \mathrm{~h}$ urinary assessment. \#: Error bars (standard deviations around the mean) are presented, when available. 


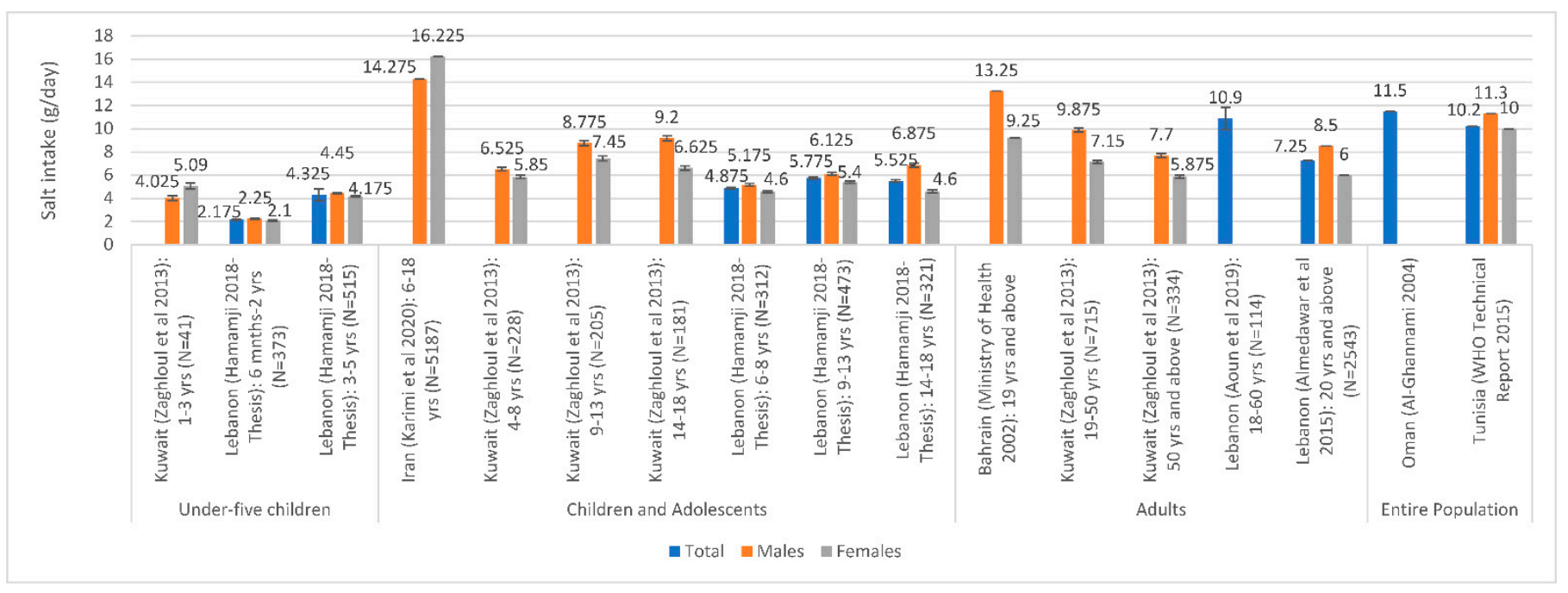

Figure 3. Salt intake estimates based on national dietary assessment studies conducted in countries of the EMR\#. Abbreviations: EMR: Eastern Mediterranean Region; WHO: World Health Organization. References: For Underfive Children: Kuwait: Zaghloul et al., 2013 [59]; Lebanon: Hamamji 2018-Thesis [67]. For Children and Adolescents: Iran: Karimi et al., 2020 [45]; Kuwait: Zaghloul et al., 2013 [59]; Lebanon: Hamamji 2018-Thesis [67]. For Adults: Bahrain: Ministry of Health 2002 [25]; Kuwait: Zaghloul et al., 2013 [59]; Lebanon: Aoun et al., 2019 [68] and Almedawar et al., 2015 [69]. For the Entire Population: Oman: Al-Ghannami 2004 [77]; Tunisia: WHO Technical Report 2015 [84]. \#: Error bars (standard deviations around the mean) are presented, when available.

\subsection{Assessment of Salt Levels in Food and Salt-Related KAB}

Data regarding the baseline levels of salt/sodium in specific foods or meals were collected in 16 countries of the EMR (73\%), including Bahrain, Egypt, Iran, Iraq, Jordan, KSA, Kuwait, Lebanon, Morocco, Oman, Pakistan, Palestine, Qatar, Tunisia, UAE, and Yemen $[27,28,43,53,69,84,91-125]$. These salt/sodium content data were collected based on food composition databases, food analysis, or industry self-reporting. Of the 22 EMR countries, the proportion measuring baseline $\mathrm{KAB}$ in relation to salt is estimated at $45 \%$. These countries include Egypt, Iran, Jordan, KSA, Lebanon, Morocco, Oman, Pakistan, Sudan, and the UAE. Most of the KAB surveys were based on questions relating to knowledge of the adverse health effects of high salt intake, attitudes towards the reduction of salt intake and its importance, as well as consumers' behavior such as adding salt to food prior to tasting, or cooking with low-salt products $[29,30,52,54,70,75,79,82,87,88,125-140]$.

\subsection{Countries with National Salt Reduction Strategies}

As shown in Table 1, national salt reduction initiatives were identified in 13 out of the 22 countries of the EMR (59\%). These 13 countries include Bahrain, Egypt, Iran, Jordan, KSA, Kuwait, Lebanon, Morocco, Oman, Palestine, Qatar, Tunisia, and the UAE. In their review, Lachat et al. (2013) mentioned that Sudan had a proposal for taxes on salty foods and that initiatives for promoting the reduction of salt intake in the population exist in Sudan and Djibouti [141]. However, we were not able to confirm or locate any further details related to these measures. Hence, for the purpose of this systematic review, Sudan and Djibouti were considered as "having a planned strategy" for the reduction of population salt intake. In addition, the GINA database included Iraq amongst countries that have implemented policies to reduce the population's salt/sodium consumption [142]. More specifically, it referred to salt reduction in bread to a required percentage of $0.5 \%$ salt on a dry flour weight basis as of 2016 [143]. However, the GINA database has also indicated that this initiative was not adopted in the country [143]. Accordingly, and given that no other salt reduction initiatives were found during our systematic search, Iraq was not considered as having national salt reduction initiatives in this review. 
Table 1. Salt reduction implementation strategies in countries of the EMR.

\begin{tabular}{|c|c|c|c|c|}
\hline Country & Engagement with Industries and Reformulation & Consumer Education & Front of Pack Labelling & Work in Specific Settings \\
\hline Bahrain & $\begin{array}{l}\text { Name of initiative: Determining the percentage of table } \\
\text { salt to be added to bakery products } \\
\text { Year: } 2018 \\
\text { Leadership: Led by the government (MOH) } \\
\text { Approach: Salt reduction in Arabic breads: Mandatory } \\
\text { (supported by ministerial decree): A } 20 \% \text { annual reduction } \\
\text { of salt level in traditional Arab breads from their current } \\
\text { levels for five years until reaching the required percentage } \\
\text { of } 0.5 \% \text { salt on a dry flour weight basis [144] } \\
\text { Mandatory: Reduction in the amount of added salt in } \\
\text { baked products during three years starting in } 2018 \text { and } \\
\text { reaching a percentage of } 0.5 \% \text { salt }[145,146] \\
\text { Cheese is under study [144] }\end{array}$ & & $\begin{array}{l}\text { Name of initiative: Determining the } \\
\text { percentage of table salt to be added } \\
\text { to bakery products } \\
\text { Year: } 2018 \\
\text { Leadership: Led by the government } \\
\text { (MOH) } \\
\text { Approach: Mandatory: Nutrition } \\
\text { labels of baked products (traditional } \\
\text { and European) should specify the } \\
\text { amount of added salt [146] }\end{array}$ & \\
\hline Egypt & $\begin{array}{l}\text { Name of initiative: NA } \\
\text { Year: } 2017 \\
\text { Leadership: Led by government (MOHAP) } \\
\text { Approach: Mandatory: ministerial decree to reduce by } \\
30 \% \text { the salt content of subsidized Baladi Bread-Planned } \\
\text { target [31] } \\
\text { Other initiatives: Voluntary: Training of bakeries on } 20 \% \\
\text { reduction of salt in bread } \\
\text { (Information provided by NFP) }\end{array}$ & $\begin{array}{l}\text { Name of initiative: Pilot Implementation } \\
\text { of 20\% Salt Reduction in Subsidized } \\
\text { Baladi Bread in Great Cairo } \\
\text { Year: 2018-2019 } \\
\text { Leadership: Led by the government } \\
\text { Approach: Awareness campaigns } \\
\text { (Information provided by NFP) } \\
\text { Name of initiative: Brief Health } \\
\text { Education sessions } \\
\text { Year: NA } \\
\text { Leadership: NA } \\
\text { Approach: Awareness activities to } \\
\text { increase consumers' awareness towards } \\
\text { hazards of high salt consumption and } \\
\text { motivate them to reduce salt consumption } \\
\text { (Information provided by NFP) }\end{array}$ & & $\begin{array}{l}\text { Name of initiative: } 100 \text { Million } \\
\text { Health Initiative } \\
\text { Year: } 2019 \\
\text { Leadership: Led by the government } \\
\text { (MOH) } \\
\text { Approach: Education } \\
\text { Setting: Hospital, school, workplace } \\
\text { (Information provided by NFP) }\end{array}$ \\
\hline
\end{tabular}


Table 1. Cont.

\begin{tabular}{|c|c|c|c|c|}
\hline Country & Engagement with Industries and Reformulation & Consumer Education & Front of Pack Labelling & Work in Specific Settings \\
\hline Iran & $\begin{array}{l}\text { Name of initiative: Adopted legislation for salt levels in } \\
\text { several products } \\
\text { Leadership: Led by the government } \\
\text { Approach: Mandatory } \\
\text { 2015: Establishing maximum salt levels in most commonly } \\
\text { consumed canned foods such as tomato paste and salty } \\
\text { snacks, and all types of bread }(1.8 \%)[91,147,148] \\
\text { 2016-2017: The standard of salt in bread was further } \\
\text { decreased to } 1 \% \text { [149-152]. } \\
\text { 2015: The standard of salt in cheese was decreased from } \\
4 \% \text { to } 3 \% \text { [152,153] } \\
\text { 2015: The standard of salt in dough (fermented drink) was } \\
\text { decreased from } 1 \% \text { to } 0.8 \% \text { [ } 152,154] \\
\text { 2018: Salt use has been banned in probiotic yogurts } \\
\text { [152,155] } \\
\text { Improvement of nutrition in public places } \\
\text { through policies for reduced salt in food } \\
\text { industries and restaurants; sensitizing food producers } \\
\text { regarding the reduction of salt in food products [141] (No } \\
\text { further details found) }\end{array}$ & $\begin{array}{l}\text { Public education through TV regarding } \\
\text { low salt consumption [141] } \\
\text { (No further details found) }\end{array}$ & $\begin{array}{l}\text { Name of initiative: Nutritional } \\
\text { traffic light labelling } \\
\text { Year: } 2016 \\
\text { Leadership: Led by the government } \\
\text { Approach: Mandatory for all } \\
\text { imported and domestic packaged } \\
\text { foods, except for products that are } \\
\text { not chemically processed or } \\
\text { formulated, such as vegetables, } \\
\text { spices, vinegar, lemon juice, tea, } \\
\text { infusions, coffee, honey, dates, flour, } \\
\text { and barberry [152] }\end{array}$ & \\
\hline Jordan & $\begin{array}{l}\text { Name of initiative: Reduction of salt in Arabic bread } \\
\text { Year: } 2019 \\
\text { Leadership: Led by the government (part of reducing salt, } \\
\text { sugar, trans fat consumption) } \\
\text { Approach: Mandatory for bread; based on partnership } \\
\text { with bakeries } \\
\text { Target for breads: Less than } 1 \% \text { of dry weight [156] } \\
\text { (planned) } \\
\text { Name of initiative: NA } \\
\text { Year: NA } \\
\text { Leadership: Led by the government } \\
\text { Approach: Revised already existing legislation to develop } \\
\text { benchmarks for salt content in highly consumed foods, } \\
\text { including cheeses [144,148] } \\
\text { (No further details found) }\end{array}$ & $\begin{array}{l}\text { Name of initiative: Low salt, sugar, and } \\
\text { trans-fat consumption } \\
\text { Year: } 2018 \\
\text { Leadership: Led by the government } \\
\text { (MOH) } \\
\text { Approach: Social marketing (e.g., } \\
\text { awareness campaigns), dietary guidelines } \\
\text { health promotion campaign } \\
\text { (No further details found) } \\
\text { Information provided by NFP } \\
\text { Develop national recommendations for } \\
\text { the reduction of salt intake [141] } \\
\text { (No further details found) }\end{array}$ & & \\
\hline
\end{tabular}


Table 1. Cont.

\section{Country Engagement with Industries and Reformulation}

Name of initiative: Healthy Food Strategy, vision 2030

Year: 2018

Leadership: Led by the government (SFDA)

Approach:

Voluntary: SFDA.FD 59 "salt limits in food product"

Mandatory: SFDA.FD 2362 "General requirements for

bread production"

Mandatory: SFDA.FD 57 “Yogurt, Flavoured Yogurt, and Yogurt Drink"

Food categories reformulated

Breads, processed meats, ready meals, breakfast cereals,

cheeses, butter and margarines, salty snacks, biscuits and

cakes, and soups and sauces

Targets for breads (mandatory): $1.0 \mathrm{~g} / 100 \mathrm{~g}$ of bread (all

types of bread) [157-160]

Mandatory salt limit for yogurt drink (Ayran Laban):

$1 \mathrm{~g} / 100 \mathrm{~mL}[160]$
Consumer Education

\section{Front of Pack Labelling}

Name of initiative:

Healthy Food Strategy, vision 2030

[159]

Year: 2018

Leadership: Led by the government (SFDA)

Name of initiative: Healthy Food Strategy vision 2030

Year: 2018

Leadership: Led by the government (SFDA)

Approach: Social marketing, events,

social media posts $[159,161]$

Name of initiative: Warns of Salt

Excessive Consumption, Presents

Substitutes

Year: 2017-2020

Leadership: Led by the government

(MOH and SFDA)

Approach: Voluntary for all food

categories

SFDA.FD 42 "Traffic light labeling"

$[166,167]$

- $\quad$ Low (green): Less than or equal to $0.3 \mathrm{~g}$ per $100 \mathrm{~g}$

- Medium (Orange): Greater

than $0.3 \mathrm{~g}$ to less than or equal

to $1.5 \mathrm{~g}$ per $100 \mathrm{~g}$

- $\quad$ High (Red): Greater than $1.5 \mathrm{~g}$ per $100 \mathrm{~g}$

For liquid food or beverages (per

$100 \mathrm{~mL}$ ):

Approach: Awareness video, guides and campaigns [162-165]

- $\quad$ Low (green): Less than or equal to $0.3 \mathrm{~g}$ per $100 \mathrm{~mL}$
Name of initiative: Healthy Food Strategy, vision 2030 [159]

Promoting healthy life style in work environment [168]

Year: 2018

Leadership: Led by the government (SFDA)

Approach: Voluntary; procurement policy and education

Setting: Workplace, schools, and

hospitals [121]

Medium (Orange): Greater than $0.3 \mathrm{~g}$ to less than or equal to $0.75 \mathrm{~g}$ per $100 \mathrm{~mL}$

- $\quad$ High (Red): Greater than 0.75 g per $100 \mathrm{~mL}$ 
Table 1. Cont.

\begin{tabular}{|c|c|c|c|}
\hline Country & Engagement with Industries and Reformulation & Front of Pack Labelling & Work in Specific Settings \\
\hline Kuwait & $\begin{array}{l}\text { Name of initiative: Kuwaitis lower blood pressure by } \\
\text { reducing salt in bread [62] } \\
\text { Year: } 2013 \\
\text { Leadership: Led by the government (MOH), in } \\
\text { partnership with Kuwait Flour Mills and Bakeries Co } \\
\text { (KFMB) } \\
\text { Approach: Voluntary-implementation of a 10\% reduction } \\
\text { of salt in pita bread, which was achieved in March 2013, } \\
\text { followed by another } 10 \% \text { reduction } 6 \text { months later in } \\
\text { August } 2013 \text {. The reduction included other white and } \\
\text { whole wheat bread varieties [ } 61] \\
\text { Revision of salt standard for cheese [144,148] } \\
\text { Name of initiative: Strategy to promote and support } \\
\text { nutrition in school children (6-18 years old) } \\
\text { Year: } 2017 \\
\text { Leadership: Led by the government-Community } \\
\text { Nutrition Promotion Sector (CNPS) of the Public } \\
\text { Authority for Food and Nutrition (PAFN) } \\
\text { Approach: Mandatory: } 6 \text { corn and potato crisp companies } \\
\text { were targeted } \\
\text { Target of salt content } \leq 1.5 \text { g/100 g [61] }\end{array}$ & & $\begin{array}{l}\text { Name of initiative: The role of } \\
\text { Administration of Food and } \\
\text { Nutrition MOH in controlling and } \\
\text { prevention of non-communicable } \\
\text { diseases in Kuwait } \\
\text { Year: } 2021 \\
\text { Leadership: Led by the government } \\
\text { (Food and Nutrition Administration } \\
\text { (FNA) on behalf of the Kuwait } \\
\text { MOH)), in cooperation with Patient } \\
\text { Helping Fund Society (PHFS) } \\
\text { Approach: Mandatory- Apply the } \\
\text { traffic light system on food items } \\
\text { sold in governmental hospital } \\
\text { cafeterias and canteens). Revision of } \\
\text { hospital menus to decrease the } \\
\text { levels of salt [169] }\end{array}$ \\
\hline Lebanon & $\begin{array}{l}\text { Name of initiative: Lebanese Action on Sodium and } \\
\text { Health (LASH) } \\
\text { Year: } 2012 \\
\text { Leadership: Led by academia in collaboration with the } \\
\text { government } \\
\text { Approach: Voluntary—assesses intake and sources of salt; } \\
\text { assesses baseline salt knowledge and improved } \\
\text { knowledge; collaborating with the Ministry of Industry } \\
\text { and MOH to develop national salt standards in bread } \\
\text { [144,170]. Legislation on salt reduction should have been } \\
\text { proposed to concerned members of Parliament) [171] }\end{array}$ & $\begin{array}{l}\text { Name of initiative: Lebanese Action on } \\
\text { Sodium and Health (LASH) } \\
\text { Year: } 2012 \\
\text { Leadership: Led by academia in } \\
\text { collaboration with the government } \\
\text { Approach: Aims to partner with a } \\
\text { communications company to develop and } \\
\text { launch a national salt reduction campaign } \\
\text { in order to raise awareness on salt } \\
\text { hazards and empower consumers to } \\
\text { make better dietary choices [170] }\end{array}$ & \\
\hline
\end{tabular}


Table 1. Cont.

\section{Country Engagement with Industries and Reformulation}

Name of initiative: Reduction of salt content in food products

Year: 2015

Morocco Leadership: Led by the government (MOH) [172]

Voluntary for bread

(No further details were identified)

\section{Consumer Education}

Name of initiative: Salt awareness

campaign for bakers

Year: 2014

Leadership: Led by the government

Approach: Awareness campaign for

bakers (around 300 bakeries) in Grand

Casablanca region; 70\% committed to

implement reduction $[144,147,148]$

Name of initiative: Reduction of salt

intake via campaigns

Year: 2015

Leadership: Led by the government $(\mathrm{MOH})$

Approach: Awareness campaign [172]

Name of initiative: Campaign for

reduction of Salt consumption

Year: Planned for 2021-2022

Name of initiative: Omani Standard for Bread [173]

Year: 2019

Leadership: Led by the government (MOCI)

Leadership: Led by the government and NGOs

Approach: The reduction of $10 \%$ of salt content started, as Approach: Social marketing campaigns,

voluntary, in late 2015 and it was followed by another 10\% TV advertising, and events (planned)

to a total of $20 \%$ in the main three bakeries supplying most (Information provided by NFP)

Oman

of the bread in the country $[174,175$

Name of initiative: World Salt Awareness

It became mandatory as of May 2019: 0.5\% (0.5 g of salt in Week

$100 \mathrm{~g}$ of bread) for flat bread (Arabic bread) [175]

For other kinds of bread such as sliced bread or French

bread: $1 \%$ ( $1 \mathrm{~g}$ of salt in $100 \mathrm{~g}$ of bread) [175]

$30 \%$ reduction of salt in food products (planned)

$[144,175,176]$

\section{Front of Pack Labelling}

Work in Specific Settings

Name of initiative: Moroccan

Nutrition Program and action plan

2017-2021

Year: NA

Leadership: Led by the government

Approach: Mandatory-FOP

Nutrition logos, Nutri-Score

(planned) [167]
Year: 2018

Leadership: Led by the government

(MOH, Nutrition department)

Approach: In line with the world's

celebration of the World Salt Awareness

Week, awareness activities are organized

during the 12th to the 18th of March [177]
Name of initiative: NA

Year: 2016

Leadership: Led by the government

(MOH)

Approach: Limit the availability of high salt items

Setting: Schools (not adopted yet) [178] 
Table 1. Cont.

\begin{tabular}{|c|c|c|c|c|}
\hline Country & Engagement with Industries and Reformulation & Consumer Education & Front of Pack Labelling & Work in Specific Settings \\
\hline Palestine & $\begin{array}{l}\text { Name of initiative: National Health Strategy, 2021-2023 } \\
\text { Year: } 2019 \\
\text { Leadership: Led by the government }(\mathrm{MOH}) \\
\text { Approach: Food categories reformulated: gradual } \\
\text { reduction of salt content in bread-mandatory; } \\
\text { Targets set by year: } 2019-0.9 \mathrm{~g} / 100 \mathrm{~g}, 2021-0.8 \mathrm{~g} / 100 \mathrm{~g} \text {, } \\
2022-0.7 \mathrm{~g} / 100 \mathrm{~g}, 2023-0.6 \mathrm{~g} / 100 \mathrm{~g} \text { [179] }\end{array}$ & & & \\
\hline Qatar & $\begin{array}{l}\text { Name of initiative: WHO Salt Reduction in Bread Initiative } \\
\text { Year: } 2013 \\
\text { Leadership: Led by the government (MOPH) (part of } \\
\text { Nutrition \& Physical Activity Action Plan 2011-2016) [180] } \\
\text { Approach: A } 20 \% \text { salt reduction in bread has already been } \\
\text { initiated in the main national bakery (Mesaieed Bakery or } \\
\text { Qbake). This reduction has also been achieved in other } \\
\text { main bakeries of the country [92,144,148,181]. The aim is } \\
\text { to reduce salt content in bread samples that contain more } \\
\text { than } 0.8 \% \text { of salt [148] } \\
\text { Targets set for bread are mandatory } \\
\text { Name of initiative: Initiative to reduce fat, sugar, and salt } \\
\text { consumption in Qatar } \\
\text { Year: } 2019 \\
\text { Leadership: Led by the government (MOPH) } \\
\text { Approach: Approach done through meetings with the } \\
\text { food industry to set voluntary commitments to fat, salt, } \\
\text { and sugar reduction. Targets for salt levels in foods, and } \\
\text { (Information provided by NFP) }\end{array}$ & $\begin{array}{l}\text { Name of initiative: Food and Beverage } \\
\text { Labelling and Calories Count Initiative at } \\
\text { Restaurants and Coffee Shops } \\
\text { Year: } 2018 \\
\text { Leadership: Led by the government } \\
\text { (MOPH and MOCI) } \\
\text { Approach: Social marketing (e.g., } \\
\text { campaigns, meetings with food } \\
\text { industries, press releases, events } \\
\text { (Information provided by NFP) } \\
\text { Name of initiative: Salt Awareness Week } \\
\text { (annually) } \\
\text { Leadership: Led by the government } \\
\text { (MOPH) } \\
\text { Approach: Social marketing (e.g., } \\
\text { campaigns, TV advertising (conducted } \\
\text { TV and radio interviews), events } \\
\text { (Information provided by NFP) } \\
\text { Name of initiative: Initiative to reduce fat, } \\
\text { sugar and salt consumption in Qatar } \\
\text { Year: } 2019 \\
\text { Leadership: Led by the government } \\
\text { (MOPH) } \\
\text { Approach: Social marketing (e.g., } \\
\text { campaigns, TV advertising (conducted } \\
\text { TV and radio interviews), events } \\
\text { (Information provided by NFP) }\end{array}$ & & $\begin{array}{l}\text { Name of initiative: Food \& Beverage } \\
\text { Guidelines; } \\
\text { School Canteen Guidelines for } \\
\text { Cafeterias and Vending Machines; } \\
\text { Educational sessions in schools and } \\
\text { workplaces } \\
\text { Year: Ongoing } \\
\text { Leadership: Led by the government } \\
\text { (MOPH) } \\
\text { Approach: Education, guidelines } \\
\text { Setting: School, hospital, workplace, } \\
\text { and public places such as grocery } \\
\text { stores and shopping malls } \\
\text { (Information provided by NFP) }\end{array}$ \\
\hline
\end{tabular}


Table 1. Cont.

\begin{tabular}{|c|c|c|c|c|}
\hline Country & Engagement with Industries and Reformulation & Consumer Education & Front of Pack Labelling & Work in Specific Settings \\
\hline Tunisia & $\begin{array}{l}\text { Name of initiative: Salt reduction program } \\
\text { Year: } 2015 \\
\text { Leadership: Led by the government } \\
\text { Approach: Salt reduction program has already started in } \\
\text { Bizerte city with the } 22 \text { bakeries; the program aims to } \\
\text { progressively reduce the salt content of bread by } 30 \% \text {, } \\
\text { voluntarily [144,147,182]. This is considered a pilot phase } \\
\text { of the national action plan } \\
\text { Name of initiative: Proposed reformulation of food } \\
\text { products to contain less salt } \\
\text { Year: } 2018 \\
\text { Leadership: Led by the government }(\mathrm{MOH})[86] \text { (planned) }\end{array}$ & $\begin{array}{l}\text { Name of initiative: Reducing salt intake } \\
\text { and helping consumers make healthier } \\
\text { choices that include less salt intakes } \\
\text { Year: } 2012 \\
\text { Leadership: Led by the government } \\
\text { (MOH) } \\
\text { Approach: NA [183] } \\
\text { Name of initiative: Media campaigns to } \\
\text { promote change in the intake of salt } \\
\text { Year: } 2018 \\
\text { Leadership: Led by the government } \\
\text { (MOH) } \\
\text { Approach: Not adopted [86] }\end{array}$ & $\begin{array}{l}\text { Name of initiative: NA } \\
\text { Year: } 2018 \\
\text { Leadership: Led by the government } \\
\text { (MOH) } \\
\text { Approach: } \\
\text { Mandatory-Recommend having } \\
\text { salt content on the FOP (planned) } \\
\text { [86,167,184]. }\end{array}$ & $\begin{array}{l}\text { Name of initiative: NA } \\
\text { Year: } 2018 \\
\text { Leadership: Led by the government } \\
\text { (MOH) } \\
\text { Approach: Create supportive } \\
\text { environments in public places by } \\
\text { offering low-salt options } \\
\text { Setting: Public places, schools, } \\
\text { workplaces } \\
\text { (not adopted yet) [86] }\end{array}$ \\
\hline
\end{tabular}


Table 1. Cont.

\section{Country Engagement with Industries and Reformulation}

\section{Consumer Education}

Name of the initiative: Reduction of salt

intake by $30 \%$ (National Action Plan)

Year: 2017

Leadership: Led by the government

(MOHAP)

Approach: Recommendations for media

campaigns and programs to spread

awareness in the population (including

nutrition labelling) and food industries,

Name of initiative: Reformulate food products (National

Action Plan)

Year: 2017

Leadership: Led by the government (MOHAP)

UAE Approach: Voluntary-reformulate breads to have less

than $0.5 \%$ salt content and reduce salt levels in other food

products such as pickles, cheeses, fast foods, snacks and

other processed food (National Action Plan) (MOHAP

Task Force on Reduction of Salt already established) [185] cafes, kiosk etc.

(MOHAP Task Force on Reduction of Salt

already established) $[185,186]$

Name of initiative: Exclude salt from your

food menu

Year: 2019

Leadership: Led by the government

MOHAP)

Approach: Instagram posts about high

medium and low salt foods [187]

Name of initiative: Pay attention to the

dangers of excessive salt intake!

Year: 2018

Leadership: Led by the government

(MOHAP)

Approach: Instagram posts about food

preparation tips to decrease salt [188]

Front of Pack Labelling

Work in Specific Settings

Name of initiative: NA

Year: 2020

Leadership: Led by the governmen

Approach: Voluntary - traffic light

labelling (Planned) - to become

mandatory as of 2022 [167]
Name of initiative: Healthy recipes for school lunch bag

Year: 2019

Leadership: Led by government

Approach: Voluntary

Setting: Schools [123]

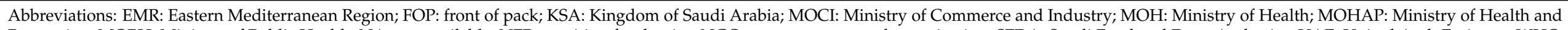

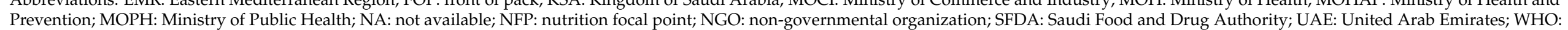
World Health Organization. 


\subsection{Leadership and Strategic Approach}

All of the identified strategies were mainly led by the government, except for Lebanon, where the salt reduction initiative was led by academia in collaboration with the government (Table 1). Except for Lebanon and Palestine, the remaining 11 countries (85\%) have established targets for population salt intake. More specifically, Bahrain, Jordan, KSA, Kuwait, Oman, and Qatar have a target of $5 \mathrm{~g}$ of salt per day, as per the WHO recommendations. The target adopted by Egypt, Iran, Tunisia, and the UAE consists of a 30\% relative reduction in salt intake, while that of Morocco is set at 10\% reduction. As shown in Table 2, salt reduction strategies in countries of the region were part of broader initiatives targeting NCD or healthy diets and lifestyles.

Table 2. National salt reduction strategies or action plans identified in countries of the EMR.

\begin{tabular}{|c|c|}
\hline Country & National Strategy and/or Action Plan \\
\hline Bahrain & $\begin{array}{l}\text { Reduce intake of salt-containing foods to less than } 5 \mathrm{~g} / \text { day amongst adults (>18 years) }-2012(\mathrm{MOH}) \\
\text { (National Action Plan for } 15 \text { years, for the Reduction of NCDs) [189] }\end{array}$ \\
\hline Egypt & $\begin{array}{l}\text { Reach a target of } 20 \% \text { relative reduction by } 2021 \text { and } 10 \% \text { relative reduction ( } 9 \mathrm{~g} / \text { day) by } 2025 \text { for adults-2017 } \\
(\mathrm{MOHP}) \text { (National Multisectoral Action Plan for Prevention and Control of NCDs 2017-2021) [31] }\end{array}$ \\
\hline Iran & $\begin{array}{l}\text { A } 30 \% \text { relative reduction in mean population intake of salt/sodium-2015 (Iranian National Committee for } \\
\text { NCDs Prevention and Control) [190] }\end{array}$ \\
\hline Jordan & $\begin{array}{l}\text { Reduction of salt intake in the population to }<5 \mathrm{~g} / \text { day-2015 (MOH) (National Strategy And Plan Of Action } \\
\text { Against Diabetes, Hypertension, Dyslipidemia And Obesity in Jordan) [191] }\end{array}$ \\
\hline KSA & $\begin{array}{l}\text { Salt reduction as per the WHO recommendation (no more than } 5 \mathrm{~g} / \text { day or } 2000 \mathrm{mg} \text { of sodium/day) - } 2018 \\
\text { (SFDA) (Healthy Food Strategy, vision 2030) }[157,159]\end{array}$ \\
\hline Kuwait & $\begin{array}{l}\text { WHO recommended maximum of } 5 \mathrm{~g} / \text { day per adult-2013 (MOH) (Kuwaitis lower blood pressure by } \\
\text { reducing salt in bread) [62] }\end{array}$ \\
\hline Morocco & $\begin{array}{l}\text { A reduction in population salt intake by } 10 \% \text { by 2025-2015 (MOH) (Prevention of NCDs: Multisectoral } \\
\text { Action Plan for a Healthy Lifestyle 2015-2020) [172] }\end{array}$ \\
\hline Oman & $\begin{array}{l}\text { Recommended salt intake: } 5 \mathrm{~g} / \text { day-2019 (MOH) (National Nutrition Strategy 2020-2030, National Plan for } \\
\text { Prevention of NCD 2016-2025) [173] }\end{array}$ \\
\hline Qatar & $\begin{array}{l}\text { Salt intake as per the WHO recommended maximum of } 5 \mathrm{~g} / \text { day for adults-2013 (MOPH) (Part of Nutrition \& } \\
\text { Physical Activity Action Plan 2011-2016) [180] }\end{array}$ \\
\hline Tunisia & $\begin{array}{l}\text { Reduce mean salt intake by } 30 \% \text { by } 2025 \text { amongst } 15 \text { year olds and above-2018 (MOH) (National } \\
\text { Multisectoral Strategy for Prevention and Control of NCDs) [86] }\end{array}$ \\
\hline UAE & Reduce population salt intake by 30\%—2017 (MOHAP) (National Action Plan in Nutrition) [185] \\
\hline \multicolumn{2}{|c|}{$\begin{array}{l}\text { Abbreviations: EMR: Eastern Mediterranean Region; KSA: Kingdom of Saudi Arabia; MOH: Ministry of Health; MOHAP: Ministry of } \\
\text { Health and Prevention; MOHP: Ministry of Health and Population; MOPH: Ministry of Public Health; NCDs: non-communicable diseases; } \\
\text { SFDA: Saudi Food and Drug Authority; UAE: United Arab Emirates; WHO: World Health Organization. }\end{array}$} \\
\hline \multicolumn{2}{|r|}{ 3.6. Implementation Strategies } \\
\hline & $\begin{array}{l}\text { Except for Palestine, all the other } 12 \text { countries are implementing multifaceted salt } \\
\text { reduction interventions, characterized by a combination of two or more implementation } \\
\text { strategies (Table 1). The least common implementation strategy in countries of the EMR is } \\
\text { taxation. Except for Qatar, where taxation of high salt products is planned, and for the UAE } \\
\text { where taxation of unhealthy salty foods was included in the National Action Plan of } 2017 \\
\text { (although not adopted yet) [185], none of the countries have initiatives that involve taxation. } \\
\text { The most common salt reduction initiative in countries of the EMR is reformulation (all of } \\
\text { the } 13 \text { countries, } 100 \%) \text {, followed by consumer education }(10 / 13 \text { countries; } 77 \% \text { ), initiatives } \\
\text { in specific settings }(7 / 13 \text { countries; } 54 \%) \text {, and FOPL ( } 6 / 13 \text { countries; } 46 \%) \text {. Table } 1 \text { shows } \\
\text { the details for the activities and initiatives implemented by the various EMR countries. }\end{array}$ \\
\hline
\end{tabular}




\subsubsection{Reformulation}

Except for Lebanon, all the reformulation initiatives in the various countries were led by governmental authorities, while engaging with the food industry. The most common food product targeted by these reformulation initiatives is bread, and in eight countries of the region, reformulation initiatives are mandatory (Bahrain, Iran, Jordan, KSA, Kuwait, Oman, Palestine, and Qatar) (8/13 countries; 62\%). Some countries have further expanded the reformulation to other food products such as cheese, salty snacks, canned foods, etc. (Iran, Jordan, KSA, Kuwait, and the UAE) (5/13 countries; 38\%).

\subsubsection{Consumer Education}

Enhancing consumer awareness and education in relation to dietary salt intake is a component of most strategies implemented in countries of the EMR. All except Bahrain, Kuwait, and Palestine have implemented consumer education campaigns (Table 1). The majority of these awareness campaigns were led by the government, except for Lebanon, where this component was led by academicians. The majority of these initiatives (80\%) were specific to salt, while others were broader campaigns in relation to healthy diets that had also included a salt component $(20 \%)$. In most countries, consumer awareness and education activities were implemented in conjunction with other salt reduction initiatives.

\subsubsection{Front of Pack Labelling}

Six countries (27\%) were found to have FOPL initiatives related to salt. These countries include Bahrain, Iran, KSA, Morocco, Tunisia, and the UAE. Mandatory traffic light labelling scheme is implemented in Iran for packaged foods. The traffic light labelling scheme is also implemented in KSA and the UAE on a voluntary basis, but it is planned to become mandatory as of 2022 in the UAE [167]. Mandatory FOPL has been also adopted by Morocco, based on the Nutriscore labelling scheme. Bahrain is implementing mandatory labelling of baked products (traditional and others), requiring the specification of the amount of added salt, while in Tunisia, mandatory FOPL of salt content is planned, but not adopted yet (Table 1).

\subsubsection{Interventions in Specific Settings}

Five countries $(23 \%)$ are implementing salt-reduction initiatives in specific settings. These include Egypt, KSA, Kuwait, Qatar, and the UAE. More specifically, health education initiatives that incorporate a salt reduction component are implemented in Egypt under the 100 Million Health initiative, in KSA under the Healthy Food Strategy, and in Qatar under the Qatar Dietary Guidelines, the Food and Beverage Guidelines and the School Canteen Guidelines, targeting healthcare facilities, schools, workplaces, and the community in general. KSA is also implementing a voluntary procurement policy to limit the procurement and hence the availability of high salt foods in these settings. Kuwait is implementing hospital menu modification as well as the labelling of foods sold in governmental hospitals, cafeterias, and canteens to reduce the consumption of high salt foods. In the UAE, the initiative related to healthy recipes for the school lunch bag promotes the consumption of low salt food. Other planned initiatives that have not been adopted yet include the creation of supportive environments by offering low salt foods in public places, schools, and the workplace in Tunisia and the limiting of the availability of high salt foods in schools in Oman.

\subsection{Monitoring}

Multisectoral national committees have already been established in Egypt, Iran, Jordan, Kuwait, Oman, Qatar, Tunisia, and the UAE (36\%) to strategize and monitor the implementation of national salt reduction strategies [144,148,185].

In Kuwait, where $80 \%$ of total bread production is produced locally by Kuwait Flour Mills and Bakeries Company (KFMBC), monitoring activities showed that the actual percentage of salt reduction in bread ranged from $12-16 \%$, mainly due to technical difficulties 
related to the taste and texture of the products [61]. In addition, as part of the strategy to promote and support nutrition in school children (6-18 years old) in Kuwait, whereby corn and potato crisp products had mandatory salt content targets, the results of monitoring activities showed that $65 \%$ of crisps products still exceeded the $1.5 \mathrm{~g} / 100 \mathrm{~g}$ target [61].

In Bahrain, a ministerial decree was formulated in 2014 in order to establish a multisectoral national committee that will work on the reduction of salt in bread products [92]. More specifically, the work of this committee will focus on developing an action plan for salt reduction, enforcing food labelling to include salt content, and developing legislation for the monitoring of salt reduction implementation [92]. Although a plan for the sampling of bread to assess for salt compliance has been developed [145,189], results pertinent to this monitoring were not published. In KSA, the Saudi Food and Drug Authority (SFDA) has conducted, in 2019, several monitoring activities, the main approach being the collection of food samples from the market to check the extent of compliance with the salt regulation set by SFDA [120]. Accordingly, compliance to the sodium/salt reduction strategies was estimated at $47 \%$ (123 items out of 261), the highest compliance having been reported for pasta $(100 \%)$, butter $(88 \%)$, cooking sauces $(92 \%)$, and pizza $(80 \%)$. The lowest compliance was observed in ready-made meals $(0 \%)$, cereals/canned vegetables/legumes $(20 \%)$, canned vegetables $(12 \%)$, and cheeses (22\%). In Qatar, the Ministry of Public Health (MOPH) is monitoring the implementation of the salt reduction policy in bread in order to ensure its sustainable implementation [148]. More specifically, bread samples are regularly collected and sent to the MOPH Central Food Laboratory to determine salt content and identify deviations from the target of $0.8 \%$ salt levels (unpublished). Accordingly, the nutritional content of any new food and beverage product that is to be potentially supplied within the schools' canteen is inspected prior to its inclusion in the canteen. In the UAE, the monitoring and evaluation of the impact of the salt reduction is included in the 2017 National Action Plan, but data on monitoring and evaluation were not found [185].

In Morocco, the knowledge of bakers as well as their commitment towards the national salt strategy was assessed [125,192]. A total of 432 bakeries from all regions in Morocco were recruited in 2018 [125] and questionnaires were administered to the bakers. The study findings showed that around $73 \%$ of the interviewed bakers were not aware of the recommendations related to the progressive reduction of salt content in bread, and $60.32 \%$ did not respect the national recommendations of $10 \mathrm{~g}$ of salt $/ \mathrm{kg}$ of flour, while $89.6 \%$ expressed their interest in getting committed to the process in the next two years [125]. Another study conducted in the region of Casablanca (Morocco) gave similar results related to the bakers' knowledge [192]. In addition, bread samples were collected from 160 bakeries in Casablanca [192]. The results showed that for white bread, average salt levels decreased from $17.8 \mathrm{~g} / \mathrm{kg}$ in 2011 to $13.1 \mathrm{~g} / \mathrm{kg}$ in 2016 (more than $25 \%$ reduction), while highlighting large discrepancies between different bakeries, with a range of 10.5 to $19.6 \mathrm{~g} / \mathrm{kg}$ [192]. In Tunisia, and more specifically, in Bizerte city, where the pilot phase of the national action plan is implemented, bread samples were collected randomly from bakeries once per week during the first three months and then, once every three months during the next period of the protocol, which extended between 2015 and 2018 [182]. Salt levels in bread was estimated at $1.7 \mathrm{~g} / 100 \mathrm{~g}$ in 2015, and this level reached $1.1 \mathrm{~g} / 100 \mathrm{~g}$ in 2018, i.e., after 3 years of implementing the salt reduction program. Hence, the average salt reduction was of $35 \%$ in bread [182]. In parallel, a pilot study on consumer acceptability of the salt-reduced bread was conducted. Results on the perception of bread saltiness by Tunisian consumers showed that a $30 \%$ salt reduction in the bread was not detected by the majority of the consumers, with $79 \%$ of the participants reporting that the salt-reduced bread had normal saltiness [182].

\subsection{Impact Assessment}

Studies or reports on impact assessment were not found for any country of the EMR. 


\section{Discussion}

This systematic review is the first to focus on salt reduction initiatives in countries of the EMR, a region that harbors a high burden of cardiovascular morbidity and mortality. It showed that, out of 22 countries in the EMR, 15 had one or more estimates of salt intake in the population (68\%), and 13 had national salt reduction strategies (59\%). The most common intervention was food reformulation through engagement with the food industry, while the least common was taxation.

Based on the most recent national studies conducted in countries of the region, the population's salt intake levels remain high, exceeding the WHO upper limit of $5 \mathrm{~g} /$ day in all countries of the EMR. In most countries, these estimates are based on studies or surveys that were collected prior to the implementation of national salt reduction initiatives and thus serve as baseline values of population salt intake. Interestingly, many of these studies have also reported on the major dietary contributors to salt intake, an information that ought to be considered in policy development and implementation. For instance, Egypt, Iraq, KSA, Kuwait, and Lebanon have identified bread and other bakery products, processed foods, ready meals, processed meats, as well as cheeses and dairy products, as the main food sources amongst adults [27-29,51,58,61,62,69]. In Iran, bread, cheese, and snacks were identified as the major contributors to salt intake amongst children aged 3-10 years [42,43], while studies conducted in Morocco reported that cereals and cerealbased products, followed by spices and condiments, dairy products, and meat products were the main sources amongst adolescents $[70,74]$.

The number of countries implementing salt reduction initiatives in the EMR has grown from 2 in 2014, as reported by Trieu et al. (2015) [10] in their global review, to 13 in 2021. This progress has been described by Santos et al. (2021) as the largest increase worldwide, reflecting the concerted efforts led by the WHO EMRO [22], which has spearheaded, over the past decade, the development of policy guidance for Member States to reduce population salt intake; set up a regional monitoring mechanism; developed a regional protocol on $24 \mathrm{~h}$ urinary sodium; and supported a network of regional research institution to conduct $24 \mathrm{~h}$ urinary sodium excretion measurements and assess dietary sodium intake [148]. The nutrition strategy 2020-2030 developed by the WHO EMRO has also included specific objectives related to the reduction of the mean population's intake of salt/sodium, in addition to recommending a number of priority actions for Member States [21].

Unlike findings reported by Santos et al. (2021), whereby interventions in settings were the most common type of salt reduction initiatives at the global level, the most common salt reduction approach in the EMR was food reformulation, which was adopted by 13 countries in the region [22]. Food reformulation was followed by consumer education interventions (10 countries), initiatives in specific settings ( 7 countries), and FOPL schemes ( 6 countries), while taxation measures have not been implemented yet. At the global level, taxation also appears as the least implemented salt reduction intervention with only $5 \%$ of countries worldwide adopting this measure [22].

Food reformulation interventions in the region have mostly focused on bread, the staple food in most countries of the EMR [91]. Studies conducted in the region have in fact shown that bread was amongst the largest contributor to salt/sodium intake in the diet $[28,84,91,109]$. Few countries such as Iran, Jordan, KSA, Kuwait, and the UAE have further expanded their food reformulation interventions to other food products, including dairy, salty snacks, processed meat, etc. This is encouraging given that studies conducted in EMR countries have identified important contributors to salt, other than bread, including cereals and cereal products [103], dairy [103,193], prepared meals [58], salted foods [193], and processed meats [193].

Consumer education was the second-most common intervention in countries of the region, with the aim of raising awareness about salt, its main dietary sources, and its health effects. Knowledge studies conducted in various countries of the EMR had in fact shown that consumers have poor knowledge related to the potential adverse effects of excessive salt consumption on health $[79,126,128,130]$, have a poor understanding of salt-related 
information on the food label $[88,130]$, and are not able to identify the main sources of salt in the diet $[88,130]$. The available few studies on salt-related attitude in the region have also revealed that only a small proportion of consumers were concerned about the amount of salt consumed in their diets [88]. At the same time, suboptimal practices were identified, with a small percentage of consumers reporting to check salt-related information on the food label $[88,130]$, while the vast majority reported to add salt during cooking or at the table $[52,79,88,126,127,131,133,134,140]$. It is recommended that countries of the region consult these $\mathrm{KAB}$ findings when developing or further tailoring their consumer education initiatives in order to address culture-specific gaps in knowledge and attitude towards salt reduction. In addition, acknowledging that FOPL can be an important element of national strategies aimed at improving the population's diets, a positive finding of this review is the fact that FOPL is being implemented or planned in six countries of the region [167]. Acknowledging that data on the main dietary contributors to salt intake is available in several countries of the region, this data ought to be consulted in a holistic manner prior to the development and implementation of salt reduction strategies to ensure that these strategies are better tailored to the local context.

This review showed that 13 countries of the EMR are implementing multifaceted national salt reduction initiatives, which is an encouraging observation, given the potential of such strategies in influencing salt intake level and hence NCD risk [194]. In fact, salt reduction is increasingly recognized as a 'best buy' intervention, which is not only costeffective, but also affordable, feasible, and culturally acceptable in any context resource setting [5]. In the EMR, the potential impact of three policies to reduce dietary salt intake were assessed: a health promotion campaign, the labelling of packaged food, and the mandatory reformulation of salt content in processed food [195]. Cumulative population health effects were quantified as life years gained (LYG) over a 10-year time frame, and all costs were calculated using the 2010 purchasing power parity exchange rates. The results showed that for Palestine, the combination of all three policies, which would lead to a $30 \%$ reduction in salt intake, would result in an estimated cost savings of $\$ 6,000,000$ and 2682 life-years gains. In Syria, the combination of these policies would lead to estimated cost savings of $\$ 39,000,000$ and 31,674 life-years gained [195], while in Tunisia, this would result in estimated cost savings of $\$ 235,000,000$ and 6455 life-years gained [195]. Another study conducted in Syria showed that the combination of reformulation with labelling, or the comprehensive policy that includes all three approaches (health promotion campaigns; food reformulation and food labelling) were the most promising salt reduction strategies to reduce CHD mortality in Syria. Approximately 32,000 life years would be saved in Syria, over a10-year period, if all three interventions were implemented [196].

This review showed that some countries of the region have incorporated a legislative component within their strategies instead of implementing solely voluntary initiatives. In fact, a mandatory approach was adopted in almost half of the countries implementing food reformulation initiatives (8 out of the 13). These countries include Bahrain, Iran, Jordan, KSA, Kuwait, Oman, Palestine, and Qatar. In addition, all of the six countries that are already implementing or planning to implement FOPL have incorporated a legislative component (Bahrain, Iran, KSA, Morocco, Tunisia, and the UAE). Kuwait has also adopted a mandatory approach within its food procurement policies, specifying salt standards for foods in public institution settings such as public schools and hospitals. Previous modeling studies as well as systematic reviews have shown that mandatory or legislative approaches tend to be more effective, producing larger reductions in salt intake levels within the population [197-199].

The implementation of clear monitoring approaches is crucial to demonstrate program effectiveness, and to incite greater changes, especially for voluntary strategies [200]. In the EMR, six countries only (Jordan, KSA, Morocco, Oman, Qatar and Tunisia) have established mechanisms for the monitoring of sodium content in one or more food categories, and using laboratory analysis. The latter is undoubtedly a highly accurate method for salt level determination, but, given its cost, it may cover only limited range of products rather than 
the whole food supply [10]. There may be a need for comprehensive surveys of salt levels in food products, based on validated product label data, an approach that can complement laboratory analysis of specific foods, to ensure that progress is made over a larger scale [34].

The assessment of the impact of salt reduction programs on population salt intake levels was not performed in any country of the EMR. For the majority of the countries, there were no available studies or surveys that have assessed salt intake after the implementation of national salt reduction initiatives. This is likely due to the fact that most salt reduction initiatives in the region are relatively recent and there has been insufficient time to assess impact. For two countries, Kuwait and Morocco, we were able to identify published studies that were conducted before and after the national initiative implementation. Compared to a baseline estimate of $4 \mathrm{~g}$ of sodium per day amongst adults in 2008 in Kuwait [60], the national survey of 2014 reported an intake ranging between 4 and $5.4 \mathrm{~g}$ of sodium per day [61,62], i.e., one year after the launch of salt reduction in bread. In both studies, the assessment of sodium intake was based on questionnaires, but details about these questionnaires and whether they were comparable were not found. In Morocco, an assessment of salt intake was conducted in 2014, in the central regions of the country via 24-h urinary excretion, reporting an estimate of $2.8 \mathrm{~g}$ of sodium per day in adults [72,73]. The national 2017-2018 survey, which was based on the collection of spot urine samples, reported an intake of $4.24 \mathrm{~g}$ of sodium per day amongst adults [70]. The 2017-2018 survey was conducted approximately two years after the initiation of salt reduction initiatives. Thus, although data may not be directly comparable, given the methodological differences between the studies, the available data does not suggest a reduction in the population's salt intake. There is a crucial need for comparative surveys to measure change in salt intake over time $[38,39]$ and hence document the programs' impact in countries of the EMR. Despite being considered the gold standard for salt intake assessment, the $24 \mathrm{~h}$ urinary sodium excretion approach can be costly while also imposing a high burden on participants, which limits its applicability to many countries of the region [20]. The collection of spot urine samples to determine $24 \mathrm{~h}$ urinary sodium excretion may thus be more applicable to large population surveys [201] and the WHO has in fact produced guidance for the monitoring of salt intake as part of STEPs, which can be adopted by countries of the region [20]. Many countries of the EMR have in fact recently adopted the STEPs spot urine protocol for salt intake assessment, but these estimates are available for one point in time only, which cannot document progress. Standardized comparable dietary approaches to measuring salt intake may also be used to document change in salt intake over time. Although dietary approaches are likely to underestimate salt intake, if the adopted method of assessment is consistent, it can still be a useful measure of change over time [201,202]. Since the regular measurement of changes in population salt intake may be complex and costly, the incorporation of process evaluations that examine the strategy implementation and its progress, collects process indicators, and identifies existing barriers and facilitators of implementation are probably more feasible and informative for identifying specific areas for improvement [203].

Government-led monitoring activities of salt-related $\mathrm{KAB}$ to assess the impact of consumer education campaigns were not found. In Morocco, the bakers' knowledge in relation to salt reduction in bread was assessed [125], but progress could not be assessed given the lack of baseline estimates. We were able to identify published studies that have assessed salt-related KAB before the implementation of consumer awareness initiatives and afterwards in four countries of the region: Jordan, KSA, Oman, and the UAE $[52,54,87,88$, $131,133,134,137,139,204]$. However, the fact that different population groups and different questionnaires were used to assess $\mathrm{KAB}$ at the two distinct time points within the countries would undoubtedly limit the comparability of the data. It is crucial that more regular evaluations of national salt reduction initiatives be conducted in countries of the region, not only to document impact at the end of the intervention, but also interim evaluations during the life of the strategy, which can allow for the incorporation of essential adaptations to foster the strategy's effectiveness [203,205]. 
This review has a number of strengths and limitations. This is the first systematic review of exiting salt reduction initiatives in countries of the EMR, their implementation, and progress towards achieving the new global target for salt reduction. In addition to the systematic search of databases and grey literature, questionnaires were sent to countries identified as having existing salt reduction initiatives and/or a country salt reduction contact person to verify and obtain supplementary country-specific data. Although not all country contacts were identified and we had some non-respondents, the triangulation of data from multiple sources allowed us to document the implementation of strategies, and present the information in a standardized manner. Through this, it is unlikely that any major salt reduction initiatives were missed, although this possibility cannot be totally excluded. Whilst one of the main strengths of the review is the fact that it included a comprehensive search of the grey literature, encompassing government reports, presentations or questionnaires completed by country program officers, a potential limitation arising from this approach is that the methodological rigor within some of the reports is unknown. More specifically, the robustness of the studies and the quality of the data used for the assessment of salt intake, salt levels in foods, and consumer KAB were not evaluated and hence should be interpreted with caution. It is also important to note that salt intake estimation may be limited by low participation and response rates, particularly in $24 \mathrm{~h}$ urine collection, which may result in sampling bias; hence, intake estimates ought to be interpreted with caution [206]. Finally, this paper did not review data pertinent to CVD incidence, CVD mortality, or prevalence of high blood pressure in countries of the region, which may have provided a deeper insight as to the impact of the study findings.

\section{Conclusions}

In conclusion, this study showed that 15 out of 22 countries of the EMR had one or more estimates of salt intake in the population $(68 \%)$, and that 13 had implemented national salt reduction strategies (59\%). The most common intervention was food reformulation, followed by consumer education interventions, initiatives in specific settings, and fourthly FOPL schemes. The impact of these interventions on the population salt intake level was not assessed, in any country of the EMR. However, based on the most recent national salt intake data, the majority of which were obtained prior to the implementation of salt reduction strategies, salt intake remains high in countries of the EMR, exceeding the WHO upper limit of $5 \mathrm{~g} /$ day. Despite the ongoing salt reduction efforts in several countries of the EMR, more action is needed to make sure that countries improve their monitoring activities, evaluate their strategies, and accelerate their efforts to meet the targeted $30 \%$ in salt intake in 2025. Countries of the region ought to develop well-designed monitoring activities to document progress within each intervention, identify gaps, and understand how the implementation process could be enhanced for better results and effectiveness.

Supplementary Materials: The following are available online at https://www.mdpi.com/article/10 .3390/nu13082676/s1, Table S1: Example of a Database Search, Table S2: Population Salt Intakes in Countries of the EMR.

Author Contributions: Conceptualization, A.A.-J. and L.N.; methodology, L.N.; investigation, A.A.-J. and L.N.; resources, A.A.-J. and L.N.; systematic database search, S.N.; data curation, M.T., A.C. and L.N.; writing—original draft preparation, L.N.; writing—review and editing, M.T. and A.A.-J.; supervision, A.A.-J. and L.N.; project administration, A.A.-J.; critical review of country-specific data and of manuscript, A.-A.M.A.-T., M.M.A., S.A., R.B., N.M.B., F.F.B., and G.F. All authors have read and agreed to the published version of the manuscript.

Funding: This research received no external funding.

Institutional Review Board Statement: Not applicable.

Informed Consent Statement: Not applicable.

Data Availability Statement: Not applicable. 
Conflicts of Interest: The authors alone are responsible for the views expressed in this article and they do not necessarily represent the views, decisions, or policies of the WHO or the other institutions with which the authors are affiliated.

\begin{abstract}
Abbreviations
CHD: coronary heart disease; CVD: cardiovascular diseases; DALYs: disability-adjusted life years; EMR: Eastern Mediterranean Region; EMRO: Regional Office for the Eastern Mediterranean; FOP: front of pack; FOPL: front of pack labelling; FFQs: food frequency questionnaires; GBD: Global Burden of Disease; GCC: Gulf Cooperation Council; GINA: Global Database on the Implementation of Nutrition Action; HBP: high blood pressure; KAB: knowledge, attitudes and behavior; KFMBC: Kuwait Flour Mills and Bakeries Company; KSA: Kingdom of Saudi Arabia; LYG: life years gained; MEHE: Ministry of Education and Higher Education; MENA: Middle East and North Africa; MOCI: Ministry of Commerce and Industry; MOH: Ministry of Health; MOHAP: Ministry of Health and Prevention; MOHP: Ministry of Health and Population; MOPH: Ministry of Public Health; MSG: monosodium glutamate; NA: not available; NCD: non-communicable disease; NFP: nutrition focal point; NGO: non-governmental organization; SDGs: Sustainable Development Goals; SFDA: Saudi Food and Drug Authority; UAE: United Arab Emirates; WHO: World Health Organization.
\end{abstract}

\title{
Appendix A
}

Table A1. List of Search Terms.

\begin{tabular}{|c|c|}
\hline Salt & salt* OR *sodium OR Na OR NaCl OR MSG \\
\hline \multicolumn{2}{|r|}{ AND } \\
\hline Reduction & $\begin{array}{l}\text { reduce* OR reduction* OR reducing OR decreas* OR limit OR limits OR limitation* OR limiting OR } \\
\text { restrict* OR reformulat* OR low* }\end{array}$ \\
\hline \multicolumn{2}{|r|}{ OR } \\
\hline Intake & $\begin{array}{l}\text { consumption OR consuming OR consume OR consumes OR intake* OR food* OR nutrition OR diet* OR } \\
\text { urinary OR excret* }\end{array}$ \\
\hline \multicolumn{2}{|r|}{ AND } \\
\hline Strategy/policy & $\begin{array}{l}\text { standard* OR polic }^{*} \text { OR initiative* OR tax* OR program* OR regulation* OR strateg* OR guideline* OR } \\
\text { practice* OR legislat* OR action* OR plan OR plans OR intervention* }^{*}\end{array}$ \\
\hline \multicolumn{2}{|r|}{ AND } \\
\hline EMR & $\begin{array}{l}\text { Afghan* OR Bahrain* OR Iran* OR Persia* OR Iraq* OR Jordan* OR Kuwait* OR Lebanon* OR Lebanese } \\
\text { OR Libya* OR Oman* OR Palestin* OR Gaza* OR "West Bank" OR Qatar* OR Saud* OR KSA OR Syria* OR } \\
\text { Tunis* OR "United Arab Emirate*" OR UAE OR Djibouti* OR Egypt* OR Morocc* OR Pakistan* OR Somal* } \\
\text { OR Sudan* OR Yemen* OR Levant* OR “East* Mediterranean" OR Gulf OR GCC OR Arab OR Arabia OR } \\
\text { Arabs OR EMR OR “Middle East" OR MENA OR “North* Africa*" OR "East* Africa*" OR "Near East*” } \\
\text { OR “Abu Dhabi" OR Dubai OR Ajman OR Fujaira* OR Sharja* OR *Khaima* OR *Qaiwain OR *Quwain }\end{array}$ \\
\hline
\end{tabular}

Abbreviations: EMR: Eastern Mediterranean Region; GCC: Gulf Cooperation Council; KSA: Kingdom of Saudi Arabia; MENA: Middle East and North Africa; MSG: monosodium glutamate; UAE: United Arab Emirates.

\section{References}

1. World Health Organization. Cardiovascular Diseases. Available online: https://www.who.int/health-topics/cardiovasculardiseases\#tab=tab_1 (accessed on 25 January 2021).

2. The World Medical Association. WMA. Statement on Hypertension and Cardiovascular Disease. Adopted by the 71st WMA General Assembly (Online); The World Medical Association: Cordoba, Spain, 2020; Available online: https://www.wma.net/policies-post/ wma-statement-on-hypertension-and-cardiovascular-disease/ (accessed on 25 January 2021).

3. He, F.J.; Li, J.; MacGregor, G.A. Effect of longer-term modest salt reduction on blood pressure. Cochrane Database Syst. Rev. 2013. [CrossRef]

4. Global Burden of Disease 2017 Risk Factor Collaborators. Global, regional, and national comparative risk assessment of 84 behavioural, environmental and occupational, and metabolic risks or clusters of risks for 195 countries and territories, 1990-2017: A systematic analysis for the global burden of disease study 2017. Lancet. 2018, 392, 1923-1994. 
5. World Health Organization. Global Status Report on Noncommunicable Diseases 2010; World Health Organization: Geneva, Switzerland, 2010; Available online: https:/ / apps.who.int/iris/bitstream/handle/10665/44579/9789240686458_eng.pdf;jsessionid=7959 C23C4871A39C6BD04E2EC915B66D?sequence=1 (accessed on 25 January 2021).

6. Mente, A.; O’Donnell, M.J.; Rangarajan, S.; McQueen, M.J.; Poirier, P.; Wielgosz, A.; Morrison, H.; Li, W.; Wang, X.; Di, C. Association of urinary sodium and potassium excretion with blood pressure. N. Engl. J. Med. 2014, 371, 601-611. [CrossRef] [PubMed]

7. O’Donnell, M.; Mente, A.; Rangarajan, S.; McQueen, M.J.; Wang, X.; Liu, L.; Yan, H.; Lee, S.F.; Mony, P.; Devanath, A. Urinary sodium and potassium excretion, mortality, and cardiovascular events. N. Engl. J. Med. 2014, 371, 612-623. [CrossRef] [PubMed]

8. Campbell, N.; Lackland, D.T.; Niebylski, M.L.; Nilsson, P.M. Is reducing dietary sodium controversial? Is it the conduct of studies with flawed research methods that is controversial? A perspective from the World Hypertension League Executive Committee. J. Clin. Hypertens. 2014, 17, 85-86. [CrossRef]

9. Alderman, M.H. Sodium and cardiovascular disease. N. Engl. J. Med. 2014, 371, 2137. [CrossRef]

10. Trieu, K.; Neal, B.; Hawkes, C.; Dunford, E.; Campbell, N.; Rodriguez-Fernandez, R.; Legetic, B.; McLaren, L.; Barberio, A.; Webster, J. Salt reduction initiatives around the world-a systematic review of progress towards the global target. PLoS ONE 2015, 10, e0130247. [CrossRef] [PubMed]

11. Milajerdi, A.; Djafarian, K.; Shab-Bidar, S. Dose-response association of dietary sodium intake with all-cause and cardiovascular mortality: A systematic review and meta-analysis of prospective studies. Public. Health Nutr. 2019, 22, 295-306. [CrossRef]

12. Sadler, K.; Nicholson, S.; Steer, T.; Gill, V.; Bates, B.; Tipping, S. National Diet E Nutrition Survey-Assessment of Dietary Sodium in Adults (Aged 19 to 64 Years) in England, 2011; Department of Health: London, UK, 2011; Available online: https://assets.publishing.service.gov.uk/government/uploads/system/uploads/attachment_data/file/213420/SodiumSurvey-England-2011_Text_to-DH_FINAL1.pdf (accessed on 27 January 2021).

13. He, F.J.; Pombo-Rodrigues, S.; MacGregor, G.A. Salt reduction in England from 2003 to 2011: Its relationship to blood pressure, stroke and ischaemic heart disease mortality. BMJ Open 2014, 4, e004549. [CrossRef]

14. World Health Organization. Noncommunicable Diseases: Campaign for Action-Meeting the NCD Targets. Available online: https: / / www.who.int/beat-ncds/take-action/targets/en/ (accessed on 25 January 2021).

15. World Health Organization. Noncommunicable Diseases and Mental Health. NCD Global Monitoring Framework. Available online: https:/ / www.who.int/nmh/global_monitoring_framework/en/ (accessed on 25 January 2021).

16. United Nations Statistics Division. Sustainable Development Goals. SDG Indicators. Available online: https://unstats.un.org/ sdgs $/$ metadata $/$ ?Text=\&Goal=3\&Target=3.4 (accessed on 25 January 2021).

17. World Development Indicators Database. Gross National Income per Capita 2015, Atlas Method and PPP. Available online: https: / / databank.worldbank.org/data/download/GNIPC.pdf (accessed on 25 January 2021).

18. Global Burden of Disease 2015 Eastern Mediterranean Region Cardiovascular Disease Collaborators. Burden of cardiovascular diseases in the Eastern Mediterranean Region, 1990-2015: Findings from the Global Burden of Disease 2015 study. Int. J. Public Health 2017, 63, 137-149.

19. Al-Jawaldeh, A.; Hammerich, A.; Doggui, R.; Engesveen, K.; Lang, K.; McColl, K. Implementation of WHO recommended policies and interventions on healthy diet in the countries of the eastern mediterranean region: From policy to action. Nutrients 2020, 12, 3700. [CrossRef]

20. World Health Organization Regional Office for the Eastern Mediterranean. Regional Strategy on Nutrition 2010-2019 and Plan of Action; World Health Organization: Cairo, Egypt, 2011; Available online: https://apps.who.int/iris/handle/10665/116694 (accessed on 27 January 2021).

21. World Health Organization Regional Office for the Eastern Mediterranean. Strategy on Nutrition for the Eastern Mediterranean Region 2020-2030; World Health Organization: Cairo, Egypt, 2019; Available online: https:/ /applications.emro.who.int/docs/97 89290222996-eng.pdf (accessed on 27 January 2021).

22. Santos, J.A.; Tekle, D.; Rosewarne, E.; Flexner, N.; Cobb, L.; Al-Jawaldeh, A.; Kim, W.J.; Breda, J.; Whiting, S.; Campbell, N. A Systematic Review of Salt Reduction Initiatives around the World: A Midterm Evaluation of Progress Towards the 2025 Global Non-Communicable Diseases Salt Reduction Target. Adv. Nutr. 2021. [CrossRef]

23. Webster, J.L.; Dunford, E.K.; Hawkes, C.; Neal, B.C. Salt reduction initiatives around the world. J. Hypertens. 2011, $29,1043-1050$. [CrossRef] [PubMed]

24. Powles, J.; Fahimi, S.; Micha, R.; Khatibzadeh, S.; Shi, P.; Ezzati, M.; Engell, R.E.; Lim, S.S.; Danaei, G.; Mozaffarian, D. Global, regional and national sodium intakes in 1990 and 2010: A systematic analysis of $24 \mathrm{~h}$ urinary sodium excretion and dietary surveys worldwide. BMJ Open 2013, 3, e003733. [CrossRef]

25. Abdul Wahab, A.; Moosa, K.; Gharib, N.; Al-Sairafi, M.; Al-Raees, G.; Al-Amer, M. National Nutrition Survey for Adult Bahrainis Aged 19 Years and Above; Ministry of Health: Manama, Kingdom of Bahrain, 2002; Available online: https: / /www.semanticscholar.org/paper/NATIONAL-NUTRITION-SURVEY-FOR-ADULT-BAHRAINIS-AGED-WahabSairafi/b5cfd2ef26840b94a1f317300303f5d389c5009e (accessed on 27 January 2021).

26. AbdEl Aal, A.; Abdul-Aziz, A.; Zaghloul, S. Construct validity of 24 hour recall estimating accuracy of energy and sodium intake. Egypt J. Nutr. 2018, 33, 1-28. 
27. Brouzes, C.M.C.; Darcel, N.; Tomé, D.; Dao, M.C.; Bourdet-Sicard, R.; Holmes, B.A.; Lluch, A. Urban Egyptian women aged 19-30 years display nutrition transition-like dietary patterns, with high energy and sodium intakes, and insufficient iron, vitamin D., and folate intakes. Curr. Dev. Nutr. 2020, 4. [CrossRef] [PubMed]

28. Zaghloul, S.; Mogeid, A.-E.; ElAal, A.; Fattah, N. Sources of dietary sodium among Egyptian adults. Egypt. J. Nutr. 2018, 3, 81-91.

29. Central Agency for Public Mobilization and Statistics; Ministry of Health and Prevention; World Health Organization. Egypt National STEPwise Survey for Noncommunicable Diseases Risk Factors Report 2017. 2018. Available online: https:/ /www.who. int/ncds/surveillance/steps/Egypt_STEPS_Survey_2017_Fact_Sheet.pdf?ua=1 (accessed on 27 January 2021).

30. Tayel, D.I.; Amine, A.K.; El-Amina, K. Dietary intake of nutrients related to bone health among Alexandria University female students, Egypt. Food Public Health 2013, 3, 329-335.

31. World Health Organization Global Database on the Implementation of Nutrition Action (GINA). Policy-Egypt National Multisectoral Action Plan for Prevention and Control of Noncommunicable Diseases (EgyptMAP-NCD)—Egypt. 2017. Available online: https:/ / extranet.who.int/nutrition/gina/en/node/25915 (accessed on 29 January 2021).

32. Gholami, A.; Rezaei, S.; Jahromi, L.M.; Baradaran, H.R.; Ghanbari, A.; Djalalinia, S.; Rezaei, N.; Naderimagham, S.; Modirian, M.; Mahmoudi, N.; et al. Is salt intake reduction a universal intervention for both normotensive and hypertensive people: A case from Iran STEPS survey 2016. Eur. J. Nutr. 2020, 59, 3149-3161. [CrossRef]

33. Rezaei, S.; Mahmoudi, Z.; Sheidaei, A.; Aryan, Z.; Mahmoudi, N.; Gohari, K.; Yoosefi, M.; Hajipour, M.J.; Dilmaghani-Marand, A.; Soleimanzadehkhayat, M.; et al. Salt intake among Iranian population: The first national report on salt intake in Iran. J. Hypertens. 2018, 36, 2380-2389. [CrossRef] [PubMed]

34. Khosravi, A.; Kelishadi, R.; Sarrafzadegan, N.; Boshtam, M.; Nouri, F.; Zarfeshani, S.; Esmaillzadeh, A. Impact of a communitybased lifestyle intervention program on blood pressure and salt intake of normotensive adult population in a developing country. J. Res. Med Sci. Off. J. Isfahan Univ. Med Sci. 2012, 17, 1-7.

35. Khosravi, A.; Toghianifar, N.; Sarrafzadegan, N.; Gharipour, M.; Azadbakht, L. Salt intake, obesity, and pre-hypertension among iranian adults: A cross-sectional study. Pak. J. Med. Sci. 2012, 28, 297-302.

36. Ministry of Health and Medical Education; Tehran University of Medical Sciences; National Institute of Health Research-Iran. Atlas of Non-Communicable Diseases Risk- Factors Surviellance in the Islamic Republic of Iran-STEPS 2016. 2016. Available online: https://www.who.int/ncds/surveillance/steps/STEPS_2016_Atlas_EN.pdf?ua=1 (accessed on 29 January 2021).

37. Arsang-Jang, S.; Mansourian, M.; Mohammadifard, N.; Khosravi, A.; Oveis-Gharan, S.; Nouri, F.; Sarrafzadegan, N. Temporal trend analysis of stroke and salt intake: A 15-year population-based study. Nutr. Neurosci. 2019. [CrossRef]

38. Mohammadifard, N.; Khosravi, A.; Salas-Salvadó, J.; Becerra-Tomás, N.; Nouri, F.; Abdollahi, Z.; Jozan, M.; Bahonar, A.; Sarrafzadegan, N. Trend of salt intake measured by 24-hour urine collection samples among Iranian adults population between 1998 and 2013: The Isfahan salt study. Nutr. Metab. Cardiovasc. Dis. 2019, 29, 1323-1329. [CrossRef] [PubMed]

39. Motlagh, Z.; Mazloomy, S.; Mozaffari Khosravi, H.; Morowatisharifabad, M.; Askarshahi, M. Salt intake among women refer to medical health centers, Yazd, Iran, 2011. SSU J. 2011, 19, 550-560.

40. Mirzaei, M.; Soltani, M.; Namayandeh, M.; Gharahi Ghehi, N. Sodium and potassium intake of urban dwellers: Nothing changed in Yazd, Iran. J. Health Popul. Nutr. 2014, 32, 111-117.

41. Emamian, M.H.; Ebrahimi, H.; Hashemi, H.; Fotouhi, A. Salt intake and blood pressure in Iranian children and adolescents: A population-based study. BMC Cardiovasc. Disord. 2021, 21. [CrossRef]

42. Kelishadi, R.; Gheisari, A.; Zare, N.; Farajian, S.; Shariatinejad, K. Salt intake and the association with blood pressure in young Iranian children: First report from the middle east and North Africa. Int. J. Prev. Med. 2013, 4, 475-483.

43. Mohammadifard, N.; Khaledifar, A.; Khosravi, A.; Nouri, F.; Pourmoghadas, A.; Feizi, A.; Esmaillzadeh, A.; Sarrafzadegan, N. Dietary sodium and potassium intake and their association with blood pressure in a non-hypertensive Iranian adult population: Isfahan salt study. Nutr. Diet. J. Dietit. Assoc. Aust. 2017, 74, 275-282. [CrossRef]

44. Rafiei, M.; Boshtam, M.; Sarraf-Zadegan, N.; Seirafian, S. The relation between salt intake and blood pressure among Iranians. Kuwait Med. J. 2008, 40, 191-195.

45. Karimi, G.; Heidari-Beni, M.; Riahi, R.; Qorbani, M.; Kelishadi, R. Healthy eating index in a nationally representative sample of children and adolescents by socio-demographic characteristics: The Weight disorders survey of the CASPIAN-IV Study. Turk. J. Pediatr. 2020, 62, 930-939. [CrossRef]

46. Mirmiran, P.; Ziadlou, M.; Karimi, S.; Hosseini-Esfahani, F.; Azizi, F. The association of dietary patterns and adherence to WHO healthy diet with metabolic syndrome in children and adolescents: Tehran lipid and glucose study. BMC Public Health $2019,19$. [CrossRef]

47. Shahriarpour, Z.; Nasrabadi, B.; Shariati-Bafghi, S.E.; Karamati, M.; Rashidkhani, B. Adherence to the dietary approaches to stop hypertension (DASH) dietary pattern and osteoporosis risk in postmenopausal Iranian women. Osteoporos. Int. 2020, 31, 2179-2188. [CrossRef]

48. Azizi, F.; Rahmani, M.; Allahverdian, S.; Hedayati, M. Effects of salted food consumption on urinary iodine and thyroid function tests in two provinces in the Islamic Republic of Iran. East. Mediterr. Health J. 2001, 7, 115-120. [PubMed]

49. Rahmani, M.; Koohkan, A.; Allahverdian, S.; Hedayati, M. Comparison of dietary iodine intake and Urinary excretion in urban and rural Households of Ilam in 2000. Iran. J. Endocrinol. Metab. 2000, 2, 31-37.

50. Kooshki, A.; Golafrooz, M. Nutrient intakes affecting bone formation compared with dietary reference intake (DRI) in Sabzevar elderly subjects. Pak. J. Nutr. 2009, 8, 218-221. [CrossRef] 
51. Ministry of Health-Iraq; World Health Organization. Noncommunicable Diseases Risk Factors STEPS Survey Iraq 2015.2015. Available online: https://www.who.int/ncds/surveillance/steps/Iraq_2015_STEPS_Report.pdf?ua=1 (accessed on 8 February 2021).

52. Alawwa, I.; Dagash, R.; Saleh, A.; Ahmad, A. Dietary salt consumption and the knowledge, attitudes and behavior of healthy adults: A cross-sectional study from Jordan. Libyan J. Med. 2018, 13. [CrossRef] [PubMed]

53. Al-Wa'l, T.; Takruri, H. Sodium and potassium intakes in a sample of students and employees in the University of Jordan aged (20-40 years) using 3-day food diaries. Nutr. Food Sci. 2016, 46, 43-50. [CrossRef]

54. Ministry of Health-Jordan. Jordan National Stepwise Survey (STEPs) for Noncommunicable Diseases Risk Factors 2019. 2020. Available online: https://www.moh.gov.jo/Echobusv3.0/SystemAssets/42e9a4d5-b719-4047-9fb6-c2b60adfee3a.pdf (accessed on 8 February 2021).

55. Alkurd, R.A. Estimated intakes of fats, cholesterol, fiber, sodium, calcium, potassium, and magnesium in Jordan. Aust. J. Basic. Appl. Sci. 2011, 5, 3171-3178.

56. Takruri, H.R.; Alkurd, R.A. Intakes of Fats, Cholesterol, Fiber and Micronutrients as Risk Factors for Cardiovascular Disease in Jordan. Jordan J. Biol. Sci. 2014, 7, 119-126. [CrossRef]

57. Alkhunaizi, A.M.; Al, J.H.; Al, S.Z. Salt intake in Eastern Saudi Arabia. East. Mediterr. Health J. 2013, 19, 915-918. [CrossRef] [PubMed]

58. Al-Khathaami, A.; Roaa, A.; Sara, Q.; Azhar, A.; Bashayer, A.; Alaa, A. Evaluation of dietary salt intake among healthy students in Riyadh, Saudi Arabia. J. Health Inform. Dev. Ctries. 2019, 13, 1-13.

59. Zaghloul, S.; Al-Hooti, S.N.; Al-Hamad, N.; Al-Zenki, S.; Alomirah, H.; Alayan, I.; Al-Attar, H.; Al-Othman, A.; Al-Shami, E.; Al-Somaie, M. Evidence for nutrition transition in Kuwait: Over-consumption of macronutrients and obesity. Public Health Nutr. 2013, 16, 596-607. [CrossRef] [PubMed]

60. Alomirah, H.; Al-Zenki, S.; Husain, A. Assessment of Acrylamide Levels in Heat-Processed Foodstuffs Consumed by Kuwaitis. Libr. Kuwait Inst. Sci. Res. Essays 2008, KISR. No. 9316. Available online: https://www.kuwaitresearch.com/ar/publication/title/ assessment-acrylamide-levels-heat-processed-foodstuffs-consumed-kuwaitis (accessed on 8 February 2021).

61. The Public Authority for Food and Nutrition-Kuwait. The Case for Investment in Prevention and Control of Non-Communicable Diseases in Kuwait; The Public Authority for Food and Nutrition: Sabah Al Salem, Kuwait, 2020.

62. World Health Organization. Kuwaitis Lower Blood Pressure by Reducing Salt in Bread. Available online: https: / / www.who.int/features/2014/kuwait-blood-pressure/en/\#: \{\}:text=But\%20in\%20Kuwait\%2C\%20cutting\%20the,most \%20 popular\%20type \%20of\%20bread (accessed on 4 March 2021).

63. Merhi, K.A. Urinary Sodium and Potassium Status of Lebanese School Aged Children; American University of Beirut: Beirut, Lebanon, 2017.

64. Nasreddine, L.; Hwalla, N.; Ismaeel, H. Validation of a Food Frequency Questionnaire for the Assessment of Sodium Dietary Intake Using 24-Hour Urine Sodium Excretion in Lebanese Adults; American University of Beirut: Beirut, Lebanon, 2014; unpublished.

65. Chouccair, S.R. Validation of a Food Frequency Questionnaire and a Spot Urine Sample for the Assessment of Dietary Sodium Intake in Lebanese Adults; American University of Beirut: Beirut, Lebanon, 2016.

66. Helou, R.M. Development and Validation of a Food Frequency Questionnaire for the Assessment of Sodium Dietary Intake in Lebanese Adults; American University of Beirut: Beirut, Lebanon, 2014.

67. Hamamji, S.E. Intakes and Sources of Fat, Free Sugars and Salt Among Lebanese Children and Adolescents; American University of Beirut: Beirut, Lebanon, 2018.

68. Aoun, C.; Daher, R.B.; Osta, N.E.; Papazian, T.; Khabbaz, L.R. Reproducibility and relative validity of a food frequency questionnaire to assess dietary intake of adults living in a Mediterranean country. PLoS ONE 2019, 14. [CrossRef]

69. Almedawar, M.M.; Nasreddine, L.; Olabi, A.; Hamade, H.; Awad, E.; Toufeili, I.; Arnaout, S.; Ismaeel, H.A. Sodium intake reduction efforts in Lebanon. Cardiovasc. Diagn. Ther. 2015, 5, 178-185.

70. Ministry of Health-Morocco. National Survey on Common Risk Factors for Non- Communicable Diseases 2017-2018. 2018. Available online: https:/ / www.sante.gov.ma/Publications/Etudes_enquete/Pages/default.aspx (accessed on 4 March 2021).

71. Saeid, N.; Elmzibri, M.; Hamrani, A.; Latifa, Q.; Belghiti, H.; El Berri, H.; Benjeddou, K.; Bouziani, A.; Benkirane, H.; Taboz, Y.; et al. Assessment of Sodium and Potassium Intakes in Children Aged 6 to 18 Years by 24 h Urinary Excretion in City of Rabat, Morocco. J. Nutr. Metab. 2018, 2018. [CrossRef]

72. Derouiche, A.; El-Kardi, Y.; Mohtadi, K.; Jafri, A. Estimation of the Daily Salt Intake by 24-Hour Urinary Sodium Excretion in Morocco: A Pilot Study. Nutrition 2016. [CrossRef]

73. Derouiche, A.; El-kardi, Y.; Mohtadi, K.; Jafri, A. Salt intake assessed by 24 hour urinary sodium excretion of Moroccan adults: A pilot study. Nutr. Clin. Metab. 2017, 31, 207-211. [CrossRef]

74. Anzid, K.; Baali, A.; Vimard, P.; Levy-Desroches, S.; Cherkaoui, M.; López, P.M. Inadequacy of vitamins and minerals among high-school pupils in Ouarzazate, Morocco. Public Health Nutr. 2014, 17, 1786-1795. [CrossRef]

75. Al-Mawali, A.; D’Elia, L.; Jayapal, S.K.; Morsi, M.; Al-Shekaili, W.N.; Pinto, A.D.; Al-Kharusi, H.; Al-Balushi, Z.; Idikula, J.; Al-Harrasi, A.; et al. National survey to estimate sodium and potassium intake and knowledge attitudes and behaviours towards salt consumption of adults in the Sultanate of Oman. BMJ Open 2020, 10. [CrossRef] [PubMed] 
76. Al-Mawali, A.; Jayapal, S.K.; Morsi, M.; Al-Shekaili, W.; Pinto, A.D.; Al-Kharusi, H.; Al-Harrasi, A.; Al-Balushi, Z.; Idikula, J. Prevalence of Risk Factors of Non-Communicable Diseases in the Sultanate of Oman: STEPS Survey 2017. Res. Sq. 2020. [CrossRef]

77. Al-Ghannami, S. National Nutrition Survey; Library of Ministry of Health, Ministry of Health: Muscat, Oman, 2004.

78. Ministry of Health-Oman. MOH Announces NCDs National Survey Results. 2018. Available online: https://www.moh.gov.om/ en/-/---896 (accessed on 4 March 2021).

79. Saqib, M.A.N.; Rafique, I.; Ansar, M.; Rahat, T. Daily Salt Intake, its Discretionary Use and Validation of Methods for Estimation using Spot Urine, Findings from Islamabad, Pakistan. medRxiv 2020. [CrossRef]

80. Rifat uz, Z.; Iqbal, Z.; Ali, U. Dietary intakes of urban adolescents of Sialkot, Pakistan do not meet the standards of adequacy. Pak. J. Nutr. 2013, 12, 460-467. [CrossRef]

81. Elmadfa, A.; Ben-Abdullah, K.; Meyer, A.; Ramlawi, A.; Bahar, L.; Rizkallah, N.; Skaik, A.; Zakout, Z.; El-Aissaw, F. Palestine Micronutrient Survey 2013; UNICEF, University of Vienna: Vienna, Austria, 2014.

82. Ministry of Health-Sudan; World Health Organization. Sudan STEPwise Survey for Non-Communicable Disease Risk Factors 2016 Report. 2016. Available online: https://www.who.int/ncds/surveillance/steps/Sudan_STEPwise_SURVEY_final_2016 .pdf?ua=1 (accessed on 4 March 2021).

83. Doggui, R.; El Ati, J.; Sassi, S.; Ben Gharbia, H.; Al-Jawaldeh, A.; El Ati-Hellal, M. Unbalanced intakes of sodium and potassium among Tunisian adults: A cross-sectional study. Food Sci. Nutr. 2021. [CrossRef]

84. World Health Organization. Report on the Technical Consultation on Salt and Fat Reduction Strategies in the Eastern Mediterranean Region, Tunis, Tunisia 30-31 March 2015; World Health Organization, Regional Office for the Eastern Mediterranean: Cairo, Egypt, 2015.

85. Aounallah-Skhiri, H.; Traissac, P.; El Ati, J.; Eymard-Duvernay, S.; Landais, E.; Achour, N.; Delpeuch, F.; Romdhane, H.B.; Maire, B. Nutrition transition among adolescents of a south-Mediterranean country: Dietary patterns, association with socio-economic factors, overweight and blood pressure. A cross-sectional study in Tunisia. Nutr. J. 2011, 10, 1-17. [CrossRef] [PubMed]

86. World Health Organization Global Database on the Implementation of Nutrition Action (GINA). Policy-Stratégie Nationale Multisectorielle de Prévention et Contrôle des Maladies Non Transmissibles (MNT)_Tunisia. 2018. Available online: https: / / extranet.who.int/nutrition/gina/en/node/39424 (accessed on 8 March 2021).

87. Jarrar, A.H.; Stojanovska, L.; Apostolopoulos, V.; Ismail, L.C.; Feehan, J.; Ohuma, E.O.; Ahmad, A.Z.; Alnoaimi, A.A.; Al Khaili, L.S.; Allowch, N.H.; et al. Assessment of sodium knowledge and urinary sodium excretion among regions of the united arab emirates: A cross-sectional study. Nutrients 2020, 12, 2747. [CrossRef]

88. Cheikh Ismail, L.; Hashim, M.; H Jarrar, A.; N Mohamad, M.; T Saleh, S.; Jawish, N.; Bekdache, M.; Albaghli, H.; Kdsi, D.; Aldarweesh, D. Knowledge, attitude, and practice on salt and assessment of dietary salt and fat intake among University of Sharjah students. Nutrients 2019, 11, 941. [CrossRef]

89. Kingdom of Morocco and World Health Organization. National Survey on Common Risk Factors for Non-Communicable Diseases 2017-2018, in STEP Wise Survey 2017-2018; Kingdom of Morocco: Rabat, Morocco, 2018.

90. Ministry of Health-Oman. National Health Survey of Non-Communicable Diseases Risk Factors; Sultanate of Oman STEPS Survey Report 2017; Center of Studies and Research: Seeb, Muscat, Oman, 2017.

91. Al Jawaldeh, A.; Al-Khamaiseh, M. Assessment of salt concentration in bread commonly consumed in the eastern mediterranean region. East. Mediterr. Health J. 2018, 24, 18-24. [CrossRef] [PubMed]

92. Alhamad, N.; Almalt, E.; Alamir, N.; Subhakaran, M. An overview of salt intake reduction efforts in the Gulf Cooperation Council countries. Cardiovasc. Diagn. Ther. 2015, 5, 172-177.

93. Musaiger, A.O.; D'Souza, R. Nutritional profile of local and western fast foods consumed in Bahrain. Ecol. Food Nutr. 2007, 46, 143-161. [CrossRef]

94. Musaiger, A.O.; D'Souza, R. The effects of different methods of cooking on proximate, mineral and heavy metal composition of fish and shrimps consumed in the Arabian Gulf. Arch. Latinoam. Nutr. 2008, 58, 103-109.

95. Zibaeenezhad, M.J.; Hooshangi, M.; Abtahi, F.; Heydari, S.T. A study of salt (sodium chloride) content in different bread consumed in shiraz city in spring/summer 2009. Iran. Cardiovasc. Res. J. 2010, 4, 17-21.

96. Ghajarbeygi, P.; Kazeminia, M.; Mahmoudi, R. Determine the quality of bread samples used in Qazvin, Iran. J. Chem. Health Risks. 2018, 8, 1-8.

97. Rezaiimofrad, M.; Jeddi, F.R.; Azarbad, Z. Baking soda and salt in bakeries of Mehrdasht (Najafabad), Isfahan, Iran: A survey on a typical rural population in a developing country. J. Prev. Med. Hyg. 2013, 54, 53-56.

98. Hashemi, M.; Afshari, A.; Aminzare, M.; Raeisi, M.; Sahranavard, T. Evaluation of pH and common salt content in bread samples produced in Mashhad, Iran. J. Food Qual. Hazards Control 2016, 3, 73-75.

99. Malakootian, M.; Dowlatshahi, S.H.; Malakootian, M. The quality of the manufactured bread and hygienic conditions of bakeries. Iran. J. Environ. Health Sci. Eng. 2005, 2, 72-78.

100. Namayandeh, S.M.; Lotfi, M.H.; Jafari, V.; Dad, V.; Biabani, J.; Razi, M.H.; Sangsefidi, Z.S. Salt content in traditional and nontraditional breads in Yazd city, Iran, 2015-2016. J. Nutr. Food. Sec. 2018, 3, 185-192. [CrossRef]

101. Habibi, N.; Fatemi, A. Survey amount of salt in consumptional bread of Sanandaj. Aust. J. Basic. Appl. Sci. 2012, 6, 90-93.

102. Hadian, Z.; Feizollahi, E.; Khosravi, K.; Mofid, V.; Rasekhi, H. Salt intake from traditional breads: A public health challenge for decreasing non-communicable diseases in Iran. Curr. Nutr. Food. Sci. 2020, 16, 1278-1284. [CrossRef] 
103. Babaali, E.; Rahmdel, S.; Berizi, E.; Akhlaghi, M.; Götz, F.; Mazloomi, S.M. Dietary intakes of zinc, copper, magnesium, calcium, phosphorus, and sodium by the general adult population aged 20-50 years in Shiraz, Iran: A total diet study approach. Nutrients 2020, 12, 3370. [CrossRef]

104. Rasheed, M.S.; Saeed, A.A.M. Evaluation of sodium concentration in different bread types in Sulaimanyah Province, Iraqi Kurdistan. Plant Arch. 2020, 20, 836-839.

105. Mbdulrahman, M.A. A study of sodium concentration in different bread consumed in Duhok city-Kurdistan region-Iraq. Duhok Med. J. 2016, 10, 20-30.

106. Hussain, F.M.A.; Takruri, H.R. A Study of Salt Content of Different Bread Types Marketed in Amman, Jordan. J. Agric. Sci. 2016, 8, 169-178. [CrossRef]

107. El-Qudah, J.M.; Dababneh, B.F.; Al-Bakheit, A.A.; Al-Qudah, M.M.; Al-Rawashdeh, A.; Khataibeh, M.; Abu-Alruz, K.; Ereifej, K.I. Nutrient contents per serving of twelve varieties of cooked rice marketed in Jordan. Am. J. Agric. Biol. Sci. 2008, 3, 617-622. [CrossRef]

108. Dashti, B.; Al-Awadi, F.; AlKandari, R.; Ali, A.; Al-Otaibi, J. Macro-and microelements contents of 32 Kuwaiti composite dishes. Food Chem. 2004, 85, 331-337. [CrossRef]

109. World Health Organization. Summary Report on the Technical Workshop on Salt and Fat Intake Reduction, Cairo, Egypt, 10-11 April 2013; WHO: Cairo, Egypt, 2013.

110. Barakat, N.G. An Assessment of Sodium Levels in Different Breads and Bread Intake in the Lebanese Population; American University of Beirut: Beirut, Lebanon, 2015.

111. Al-Jawaldeh, A.; Hoteit, M.; Zoghbi, E.; Al Iskandarani, M.; Rady, A.; Shankiti, I.; Matta, J. Nutritional value of the Middle Eastern diet: Analysis of total sugar, salt, and iron in Lebanese traditional dishes. F1000Res 2020, 9. [CrossRef]

112. Derouiche, A.; Jafri, A.; ElKardi, Y.; Jabari, M.; Habbal, R.; El Attaoui, K.; Alami, M. Should bread be targeted as a vector to reduce sodium intake in Morocco? PeerJ Prep. 2014, 2, e188v181.

113. Jafri, A.; El-Kardi, Y.; Derouiche, A. Sodium chloride composition of commercial white bread in Morocco. East. Mediterr. Health J. 2017, 23, 708-710. [CrossRef]

114. Waseem, A.; Nafees, M.; Murtaza, G.; Sajjad, A.; Mehmood, Z.; Siddiqi, A.R. Salt toxicity (sodium intake): A serious threat to infants and children of Pakistan. Iran J. Public Health 2014, 43, 1204. [PubMed]

115. Ramlawi, A.; Rub, A.A.; Materia, E.; Rossi, L.; Shuabi, N.; Barone, M.; Racalbuto, V. Reducing dietary salt consumption in the occupied Palestinian territory: A cross-sectional survey. Lancet 2018, 391, S4. [CrossRef]

116. AbuKhader, M.; Abdelraziq, R.; Al-Azawi, M.; Ali, S.K. A comparative examination of dietary sodium content in bread and its public consumption pattern in Muscat, Oman. Nutr. Food Sci. 2019, 50, 116-130. [CrossRef]

117. Musaiger, A.O.; Ahmed, M.A.; Rao, M.V. Chemical composition of some traditional dishes of Oman. Food Chem. 1998, 61, 17-22. [CrossRef]

118. Soomro, S.I.; Memon, N.; Bhanger, M.I.; Memon, S.; Memon, A.A. Mineral content of Pakistani foods: An update of food composition database of Pakistan through indirect method. J. Food Compos. Anal. 2016, 51, 45-54. [CrossRef]

119. ElObeid, T.; Phoboo, S.; Magdad, Z. Proximate and mineral composition of indigenous Qatari dishes: Comparative study with similar Middle Eastern dishes. J. Food. Chem. Nutr. 2015, 3, 27-34.

120. Saudi Food and Drug Authority. Report Clear Boundaries of Salt Saudi Standard: Maximum Guideline Limits for Salt in "Food Products"; SFDA: Riyadh, Saudi Arabia, 2019.

121. Saudi Food and Drug Authority. Healthy Food Recipes for School Lunch Bag; SFDA: Riyadh, Saudi Arabia, 2020.

122. Habib, H.M.; Ali, H.I.; Ibrahim, W.H.; Afifi, H.S. Nutritional value of 10 traditional dishes of the United Arab Emirates. Ecol. Food. Nutr. 2011, 50, 526-538. [CrossRef] [PubMed]

123. Ministry of Health-UAE. Healthy Recipes for School Lunch Bag. MA'KOM for a Balanced Diet, 1st ed.; Health Education and Promotion Department: Dubai, United Arab Emirates, 2019.

124. Al-Mussali, M.S.; Al-Gahri, M.A. Nutritive value of commonly consumed bread in Yemen. J. Chem. 2009, 6, 437-444. [CrossRef]

125. Bouhamida, M.; Nada, B.; Guennoun, Y.; Lachguer, S.A.; Elhaloui, N.E.; Zahrou, F.E.; Mounach, S.; Kari, K.E.; Al-Jawaldeh, A.; Barkat, A.; et al. Implementing the national strategy of salt reduction in Morocco: The baker's perspective. Pan. Afr. Med. J. 2020, 37. [CrossRef]

126. Pirasteh, A.; Pouraram, H.; Kholdi, N.; Abtahi, M. Discretionary salt intake and readiness for behavioral change among women in Tehran. Int. J. Prev. Med. 2019, 10. [CrossRef]

127. Jahangard, L.; Behmanesh, H.; Ahmadpanah, M.; Poormoosavi, S.M.; Solitanian, A.; Highighi, M. Risky behaviors and healthpromoting behaviors in young adults: An epidemiological study. Iran. J. Psychiatry 2019, 14, 302-308. [CrossRef]

128. Ministry of Public Health-Lebanon; World Health Organization. WHO STEPwise Approach for Non-Communicable Diseases Risk Factor Surveillance Lebanon, 2016-2017. 2017. Available online: https://www.who.int/ncds/surveillance/steps/Lebanon_ STEPS_report_2016-2017.pdf?ua=1 (accessed on 15 March 2021).

129. Bou-Mitri, C.; Khnaisser, L.; Ghanem, M.B.; Merhi, S.; Fares, J.E.; Doumit, J.; Farhat, A.G. Consumers' exposure to claims on pre-packed bread: The case of a developing country, Lebanon. Nutr. Food Sci. 2020, 50, 1033-1051. [CrossRef]

130. Nasreddine, L.; Akl, C.; Al-Shaar, L.; Almedawar, M.M.; Isma'eel, H. Consumer knowledge, attitudes and salt-related behavior in the Middle-East: The case of Lebanon. Nutrients 2014, 6, 5079-5102. [CrossRef] 
131. Al-Riyami, H.; Al-Abdulsalam, Q.; Al-Khayari, A.; Al-Mushrafi, H.; Al-Alawi, Z.; Al-Hashmi, K.; Nadar, S.K. Awareness of the dangers of high salt intake among the urban omani population. Sultan Qaboos Univ. Med. J. 2020, 20, e352-e356. [CrossRef]

132. Manickavasagan, A.; Al-Mahdouri, A.A.; Al-Mufargi, A.M.S.; Al-Souti, A.; Al-Mezeini, A.S.M.; Essa, M.M. Healthy eating knowledge among college students in Muscat: A self reported survey. Pak. J. Nutr. 2014, 13, 397-403. [CrossRef]

133. Saeedi, M.; AlMadani, A.; Alsafi, Y.; Arif, S.; Mustafa, S.; Jamo, A. Estimation of Sodium and Potassium Intake in 24-Hours Urine, Aljouf Region, Northern Saudi Arabia. Chronic. Dis. Int. 2017, 4, 1026.

134. Hanbazaza, M.A.; Mumena, W.A. Knowledge and practices related to salt intake among saudi adults. Int. J. Environ. Res. Public Health 2020, 17, 5749. [CrossRef] [PubMed]

135. Alfaifi, A.H.; Al-Harthi, D.A.; Al-Omran, G.H.; Algorashi, R.A.; Assiri, S.A.A.; Alsufyani, A.A.; Ali, M.M.; Baabbad, H.S. Knowledge, perceptions, and lifestyle behavior modifications and changes related to hypertension in Taif city, Saudi Arabia. Indo. Am. J. Pharm. Sci. 2018, 5, 15973-15984. [CrossRef]

136. Attlee, A.; Abu-Qiyas, S.; Obaid, R.S. Assessment of nutrition knowledge of a university community in Sharjah, United Arab Emirates. Malays. J. Nutr. 2014, 20, 327-337.

137. Shaikh, R.B.; Mathew, E.; Sreedharan, J.; Muttappallymyalil, J.; Sharbatti, S.A.; Basha, S.A. Knowledge regarding risk factors of hypertension among entry year students of a medical university. J. Fam. Community Med. 2011, 18, 124-129. [CrossRef]

138. El Rhazi, K.; Bennani, B.; El Fakir, S.; Boly, A.; Bekkali, R.; Zidouh, A.; Nejjari, C. Public awareness of cancer risk factors in the Moroccan population: A population-based cross-sectional study. BMC Cancer 2014, 14. [CrossRef] [PubMed]

139. Ministry of Health and Prevention-UAE. UAE Nutritional Status Study; Statistic and Research Center: Abu Dhabi, United Arab Emirates, 2020.

140. Alkhalaf, M.; Edwards, C.; Combet, E. Validation of a food frequency questionnaire specific for salt intake in Saudi Arabian adults using urinary biomarker and repeated multiple pass 24-hour dietary recall. Proc. Nutr. Soc. 2015, 74. [CrossRef]

141. Lachat, C.; Otchere, S.; Roberfroid, D.; Abdulai, A.; Seret, F.M.A.; Milesevic, J.; Xuereb, G.; Candeias, V.; Kolsteren, P. Diet and Physical Activity for the Prevention of Noncommunicable Diseases in Low- and Middle-Income Countries: A Systematic Policy Review. PLoS Med. 2013, 10. [CrossRef]

142. World Health Organization Global Health Observatory. Policies, Strategies and Action Plans: Data by Country. Available online: https: / / apps.who.int/gho/data/view.main.2473 (accessed on 3 March 2021).

143. World Health Organization Global Database on the Implementation of Nutrition Action (GINA). First Amendment/2016 Iraqi Standard 1989/1967 for (Bread)—Iraq. 2016. Available online: https:/ / extranet.who.int/nutrition/gina/en/node/39495 (accessed on 3 March 2021).

144. World Health Organization Regional Office for the Eastern Mediterranean. WHO-EM/NUT/268/E-Report on the Technical Consultation on Salt and Fat Reduction Strategies in the Eastern Mediterranean Region; World Health Organization: Tunis, Tunisia, 2015; Available online: https:/ / applications.emro.who.int/docs/IC_Meet_Rep_2015_EN_16339.pdf (accessed on 3 March 2021).

145. Ministry of Health-Bahrain. Determining the Percentage of Additives of Table Salt in Popular and Automatic Bakery Products; Ministry of Health-Bahrain: Manama, Bahrein, 2018.

146. World Health Organization Global Database on the Implementation of Nutrition Action (GINA). Policy-Resolution No. (28) of 2018 Determining the Proportions of Adding Table Salt in Popular and Automatic Bakery Products-Bahrain. 2018. Available online: https: / / extranet.who.int/nutrition/gina/en/node/39382 (accessed on 3 March 2021).

147. Morocco, O. Moving forward on salt and fat reduction in the Region. East. Mediterr. Health J. 2015, $21,374$.

148. Al Jawaldeh, A.; Rafii, B.; Nasreddine, L. Salt intake reduction strategies in the Eastern Mediterranean Region. East. Mediterr. Health J. 2018, 24, 1172-1180. [CrossRef]

149. Hajifaraji, M.; Abdollahi, Z. The Challenges and Successes of Salt, Sugar and Fat Reduction Program to Prevent Ncds (IRAN EXPERIENCES). In Annals of Nutrition and Metabolism; Karger: Basel, Switzerland, 2017; p. 345.

150. Tehran: Iranian National Standardization Organization. Traditional Breads: Specifications and Test Methods. INSO A1-2628. Amendment No. 1; 2016. Available online: http:/ / isiri.gov.ir/en/portal/home/?331765/ISIRI-Portal (accessed on 12 April 2021).

151. Tehran: Iranian National Standardization Organization. Bulk Breads-Specifications and Test Methods. INSO 2338. Second Revision; 2017. Available online: http:/ / standard.isiri.gov.ir/StandardView.aspx?Id=49200 (accessed on 12 April 2021).

152. Moslemi, M.; Kheirandish, M.; Mazaheri, N.; Hosseini, H.; Jannat, B.; Mofid, V. National food policies in the Islamic Republic of Iran aimed at prevention of noncommunicable diseases. East. Mediterr. Health J. 2020, 26, 1556-1564. [CrossRef]

153. Tehran: Iranian National Standardization Organization. Milk and Milk Products—Fresh Cheese: Specifications and Test Methods. INSO 6629. First Revision; 2015. Available online: http:/ / standard.isiri.gov.ir/StandardView.aspx?Id=47440 (accessed on 12 April 2021).

154. Tehran: Iran Food and Drug Administration. Production and Expiration Date of Dairies. Circular Letter 122509/675. FB-Ci-13940107; 2015. Available online: http:/ / isiri.gov.ir/en/portal/home/?331765/ISIRI-Portal (accessed on 12 April 2021).

155. Tehran: Iranian National Standardization Organization. Probiotic Yoghurt: Specifications and Test Methods. INSO A2-11325. Amendment No. 2; 2018. Available online: http://standard.isiri.gov.ir/StandardView.aspx?Id=49953 (accessed on 12 April 2021).

156. Jordanian Standards and Metrology Organization. JS 19: 2019_Cereals, Pulses and Derived Products—Bread. 2019. Available online: http:/ / www.jsmo.gov.jo/En/EServices/Standards/Pages/stdDetails.aspx?mfn=5883 (accessed on 12 April 2021).

157. Saudi Food and Drug Authority. SFDA.FD 59: Salt Limits In Food Products; SFDA: Riyadh, Saudi Arabia, 2018.

158. Saudi Food and Drug Authority. Technical Production of Bread Requirements; SFDA: Riyadh, Saudi Arabia, 2018. 
159. Saudi Food and Drug Authority. Healthy Food Strategy; SFDA: Riyadh, Saudi Arabia, 2018.

160. Saudi Food and Drug Authority. SFDA.FD 57: Laban, Flavoured Laban and Laban Drink; SFDA: Riyadh, Saudi Arabia, 2018.

161. Saudi Food and Drug Authority. Consumer Education and Behavior. 2018. Available online: https://old.sfda.gov.sa/ar/ awareness/Campaigns/Pages/HFStrategy.aspx (accessed on 31 May 2021).

162. Ministry of Health-Saudi Arabia. MOH Warns of Salt Excessive Consumption, Presents Substitutes. MOH News, 28 March 2017.

163. Saudi Food and Drug Authority. Awareness Campaign: Salt. Available online: https://www.sfda.gov.sa/ar/awarenesscampaign/ 74342 (accessed on 31 May 2021).

164. Saudi Food and Drug Authority. Guide for Manufacturers and Importers: Salt Limits in Food Products. 2020. Available online: https:/ / www.sfda.gov.sa/sites/default/files/2020-01/Giud04.pdf (accessed on 31 May 2021).

165. Saudi Food and Drug Authority. Guide for Bread Manufacturers and Importers: Applying the SFDA.FD 2362 “Technical Production of Bread Requirements". 2020. Available online: https://www.sfda.gov.sa/sites/default/files/2020-12/ReduceSaltBbread. pdf (accessed on 31 May 2021).

166. Saudi Food and Drug Authority. SFDA.FD 42: Traffic Light Labeling; SFDA: Riyadh, Saudi Arabia, 2018.

167. Al-Jawaldeh, A.; Rayner, M.; Julia, C.; Elmadfa, I.; Hammerich, A.; McColl, K. Improving nutrition information in the eastern Mediterranean region: Implementation of front-of-pack nutrition labelling. Nutrients 2020, 12, 330. [CrossRef]

168. Saudi Food and Drug Authority. Initiative to Promote Public Health through Food in a Work Environment. 2018. Available online: https: / / old.sfda.gov.sa/ar/awareness/Campaigns/Documents/FOOD-PublicHealth.pdf (accessed on 31 May 2021).

169. Administration of Food and Nutrition, Ministry of Health-Kuwait. The Role of Administration of Food and Nutrition Ministry of Health in Controlling and Prevention of Non-Communicable Diseases in Kuwait; Ministry of Health: Kuwait City, Kuwait, 2021.

170. American University of Beirut Medical Center. Lebanese Action on Sodium and Health. Available online: https://www.aub.edu. $\mathrm{lb} / \mathrm{fm} / \mathrm{vmp} /$ Pages/Lebanese-Action-on-Sodium-and-Health-.aspx (accessed on 19 January 2021).

171. World Health Organization Global Database on the Implementation of Nutrition Action (GINA). Policy-Non Communicable Disease Prevention and Control Plan (NCD-PCP) for Lebanon 2015-2020-Lebanon. 2014. Available online: https: / / extranet. who.int/nutrition/gina/en/node/26377 (accessed on 3 March 2021).

172. World Health Organization Global Database on the Implementation of Nutrition Action (GINA). Policy-Prevention des Maladies Non Transmissibles: Plan D'action Multisectoriel Pour la Promotion d'un Mode de vie sain 2015-2020-Morocco. 2015. Available online: https:/ / extranet.who.int/nutrition/gina/en/node/36194 (accessed on 3 March 2021).

173. Ministry of Health-Oman. Omani Standard for Bread; Ministry of Health: Muscat, Oman, 2019.

174. World Health Organization. Oman's Experience on Salt Reduction in Bread. Available online: https://www.who.int/beat-ncds/ countries/oman/salt-reduction/en/ (accessed on 16 April 2021).

175. World Health Organization Global Database on the Implementation of Nutrition Action (GINA). Ministerial Decision No. 2019/95 Omani Standard for Bread-Oman. 2019. Available online: https:/ / extranet.who.int/nutrition/gina/en/node/39755 (accessed on 3 March 2021).

176. Ministry of Health-Oman. National Nutrition Strategy 2020-2030; Ministry of Health: Muscat, Oman, 2016.

177. Ministry of Health-Oman. World Salt Awareness Week. Available online: https://www.moh.gov.om/documents/10194/569871 /\%D8\%A7\%D9\%84\%D8\%A8\%D9\%88\%D8\%B3\%D8\%AA \%D8\%B1+\%D8\%B9\%D9\%86+\%D8\%A7\%D8\%B3\%D8\%A8\%D9\%8 8\%D8\%B9+\%D8\%A7\%D9\%84\%D8\%AA \%D9\%88\%D8\%B9\%D9\%8A\%D8\%A9+\%D8\%B9\%D9\%86+\%D8\%A7\%D9\%84\%D9\%8 5\%D9\%84\%D8\%AD+\%281\%29.pdf/aa45b36a-eef2-7e22-a7a5-203706ec5993 (accessed on 4 March 2021).

178. World Health Organization Global Database on the Implementation of Nutrition Action (GINA). Policy-National Plan for the Prevention and Control of Chronic Non-Communicable Diseases 2016-2025-Oman. 2016. Available online: https:/ / extranet. who.int/nutrition/gina/en/node/39383 (accessed on 3 March 2021).

179. Ministry of Health-Palestine. National Health Strategy 2021-2023. 2019. Available online: http://site.moh.ps/Content/Books/ Byh2ENRn64uTVaLncGL6AjD1Z3dzHMEuLvgQDEC55ujpNihg8YPEVv_OTxQv6uPfFIRmT9xs7dwgvatwShEN8VoqHs83y5 NWwua3THGRD73OO.pdf (accessed on 3 March 2021).

180. World Health Organization Global Database on the Implementation of Nutrition Action (GINA). Policy-National Nutrition and Physical Activity Action Plan-Qatar. 2011. Available online: https:/ / extranet.who.int/nutrition/gina/sites/default/filesstore/ QAT\%202011\%20National\%20Nutrition\%20and\%20Physical\%20Activity\%20Action\%20Plan.pdf (accessed on 3 March 2021).

181. World Action on Salt and Health. Qatar. Available online: http://www.worldactiononsalt.com/worldaction/middle-east/qatar/ (accessed on 16 April 2021).

182. El Ati, J.; Doggui, R.; Ati-Hellal, M.E. A successful pilot experiment of salt reduction in tunisian bread: $35 \%$ gradual decrease of salt content without detection by consumers. Int. J. Environ. Res. Public Health 2021, 18, 1590. [CrossRef]

183. World Health Organization Global Database on the Implementation of Nutrition Action (GINA). Policy—Stratégie de Prévention et de Lutte contre l'Obésité-Tunisia. 2013. Available online: https:/ / extranet.who.int/nutrition/gina/en/node/23769 (accessed on 3 March 2021).

184. Buse, K.; Aftab, W.; Akhter, S.; Phuong, L.B.; Chemli, H.; Dahal, M.; Feroz, A.; Hofiani, S.; Pradhan, N.A.; Anwar, I. The state of diet-related NCD policies in Afghanistan, Bangladesh, Nepal, Pakistan, Tunisia and Vietnam: A comparative assessment that introduces a 'policy cube'approach. Health Policy Plan. 2020, 35, 503-521. [CrossRef] [PubMed]

185. World Health Organization Global Database on the Implementation of Nutrition Action (GINA). Policy-National Action Plan in Nutrition-UAE. 2017. Available online: https:// extranet.who.int/nutrition/gina/en/node/37425 (accessed on 3 March 2021). 
186. World Health Organization Global Database on the Implementation of Nutrition Action (GINA). Policy-National Plan for Prevention and Response For noncommunicable diseases State of United Arab Emirates-UAE. 2017. Available online: https: / / extranet.who.int/nutrition/gina/en/node/38165 (accessed on 3 March 2021).

187. Ministry of Health and Prevention-UAE. Exclude Salt from Your Food Menu. 2019. Available online: https://www.instagram. $\mathrm{com} / \mathrm{p} /$ BulORCQBQdc/ (accessed on 4 March 2021).

188. Ministry of Health and Prevention-UAE. Pay Attention to the Dangers of Excessive Salt Intake! 2018. Available online: https: / / www.instagram.com/p/BglH1-lH2XI/?taken-by=mohapuae (accessed on 4 March 2021).

189. World Health Organization Global Database on the Implementation of Nutrition Action (GINA). Policy-Bahrain's Health Agenda. Health Improvement Strategy—Bahrain. 2012. Available online: https:/ / extranet.who.int/nutrition/gina/en/node/17830 (accessed on 4 March 2021).

190. World Health Organization Global Database on the Implementation of Nutrition Action (GINA). Policy-National Document for Prevention and Control of Non Communicable Diseases and the Related Risk Factors in the Islamic Republic of Iran, 2015-2025-Iran. 2015. Available online: https:/ / extranet.who.int/nutrition/gina/en/node/40358 (accessed on 4 March 2021).

191. World Health Organization Global Database on the Implementation of Nutrition Action (GINA). Policy-The National Strategy and Plan of Action Against Diabetes, Hypertension, Dyslipidemia and Obesity in Jordan-Jordan. 2015. Available online: https:/ / extranet.who.int/nutrition/gina/en/node/25926 (accessed on 4 March 2021).

192. Derouiche, A.; El-Kardi, Y.; Farhloul, F.-Z.; Mokhantar, K.; Jafri, A. Impact of awareness campaigns on lowering sodium levels in commercial white bread in Morocco. In Proceedings of the IUNS 21st International Congress of Nutrition, Buenos Aires, Argentina, 15-20 October 2017; Volume 71, p. 1237.

193. Khalil, G.M.; Azqul, M.M. Assessment of Dietary Sodium Intake among Adolescent School Students at Met-Ghamer City, Al-Dakahlia Governorate, Egypt. Zagazig Univ. Med. J. 2018. [CrossRef]

194. Beaglehole, R.; Bonita, R.; Horton, R.; Adams, C.; Alleyne, G.; Asaria, P.; Baugh, V.; Bekedam, H.; Billo, N.; Casswell, S. Priority actions for the non-communicable disease crisis. Lancet 2011, 377, 1438-1447. [CrossRef]

195. Mason, H.; Shoaibi, A.; Ghandour, R.; O’Flaherty, M.; Capewell, S.; Khatib, R.; Jabr, S.; Unal, B.; Sözmen, K.; Arfa, C. A cost effectiveness analysis of salt reduction policies to reduce coronary heart disease in four Eastern Mediterranean countries. PLoS ONE 2014, 9, e84445. [CrossRef]

196. Wilcox, M.L.; Mason, H.; Fouad, F.M.; Rastam, S.; Al Ali, R.; Page, T.F.; Capewell, S.; O’Flaherty, M.; Maziak, W. Cost-effectiveness analysis of salt reduction policies to reduce coronary heart disease in Syria, 2010-2020. Int. J. Public Health 2015, 60, 23-30. [CrossRef] [PubMed]

197. Hyseni, L.; Elliot-Green, A.; Lloyd-Williams, F.; Kypridemos, C.; O’Flaherty, M.; McGill, R.; Orton, L.; Bromley, H.; Cappuccio, F.P.; Capewell, S. Systematic review of dietary salt reduction policies: Evidence for an effectiveness hierarchy? PLoS ONE 2017, 12, e0177535. [CrossRef] [PubMed]

198. Nghiem, N.; Blakely, T.; Cobiac, L.J.; Pearson, A.L.; Wilson, N. Health and economic impacts of eight different dietary salt reduction interventions. PLoS ONE 2015, 10, e0123915. [CrossRef] [PubMed]

199. Hope, S.F.; Webster, J.; Trieu, K.; Pillay, A.; Ieremia, M.; Bell, C.; Snowdon, W.; Neal, B.; Moodie, M. A systematic review of economic evaluations of population-based sodium reduction interventions. PLoS ONE 2017, 12, e0173600. [CrossRef]

200. Webster, J.; Trieu, K.; Dunford, E.; Hawkes, C. Target salt 2025: A global overview of national programs to encourage the food industry to reduce salt in foods. Nutrients 2014, 6, 3274-3287. [CrossRef]

201. McLean, R.M. Measuring population sodium intake: A review of methods. Nutrients 2014, 6, 4651-4662. [CrossRef]

202. World Health Organization. Reducing Salt Intake in Populations: Report of a WHO Forum and Technical Meeting, 5-7 October 2006, Paris, France; World Health Organization: Geneva, Switzerland, 2007; Available online: https://www.who.int/dietphysicalactivity / Salt_Report_VC_april07.pdf (accessed on 4 March 2021).

203. Trieu, K.; Michael, V.; Mustapha, F.; Lo, Y.-R.; Webster, J. Midterm Evaluation of Malaysia's National Salt Reduction StrategyLessons Learned on Adapting Salt Reduction 'Best Buys' to the Local Context. Curr. Dev. Nutr. 2020, 4, 288. [CrossRef]

204. World Health Organization. Oman STEPS Survey: Data Book. Noncommunicable Disease Risk Factor Surveillance. 2017. Available online: https://www.who.int/ncds/surveillance/steps/Oman_STEPS_2017_Data_Book.pdf?ua=1 (accessed on 4 March 2021).

205. Ministry of Health-Malaysia; World Health Organization Representative Office for Malaysia BD and Singapore. Reducing Salt Intake in Malaysia: An Interim Evaluation of What Works; Ministry of Health: Putrajaya, Malaysia, 2019; Available online: https://www.moh.gov.my/moh/resources/Penerbitan/Rujukan/NCD/Garam/CaseStudy-SALT-High-Print.pdf (accessed on 4 March 2021).

206. John, K.A.; Cogswell, M.E.; Campbell, N.R.; Nowson, C.A.; Legetic, B.; Hennis, A.J.; Patel, S.M. Accuracy and usefulness of select methods for assessing complete collection of 24-hour urine: A systematic review. J. Clin. Hypertens. 2016, 18, 456-467. [CrossRef] 